\title{
The Untold Story of Noncriminal Habeas Corpus and the 1996 Immigration Acts
}

\author{
Jonathan L. Hafetz
}

In 1996, Congress passed and the President signed the Antiterrorism and Effective Death Penalty Act (AEDPA) ${ }^{1}$ and the Illegal Immigration Reform and Immigrant Responsibility Act (IIRIRA), ${ }^{2}$ which seek to curtail judicial review of final orders of deportation for legal permanent residents convicted of certain enumerated criminal offenses. ${ }^{3}$ The acts threaten to entrust the deportation process from beginning to end to the executive branch without any opportunity for judicial review, ${ }^{4}$ notwithstanding the practical ${ }^{5}$ and symbolic ${ }^{6}$ importance of judicial review in this context. The acts thus raise jurisdictional issues of great importance, and they portend a sea change in immigration law that endangers the judiciary's role in safeguarding the rights of all individuals.

As a consequence of the acts, courts arguably may be foreclosed from reviewing a range of legal questions, including whether the acts' elimination

1. Pub. L. No. 104-132, 110 Stat. 1214 (1996) (codified in seattered sections of 8. 15, 18, 22, 28, 40. 42, \& 50 U.S.C.A. (West Supp. 1997)).

2. Pub. L. No. 104-208, 110 Stat. $3009-546$ (1996) (codified in scattered sections of 8.18 , \& 42 U.S.C.A.).

3. See AEDPA $\$ 440$ (a), 110 Stat. at 1276-77 (“Any final order of deportation aganst an alıen who is deportable by reason of having committed [certain crmes] . . . shall not be subject to review by any court.") (amending 8 U.S.C. $\$ 1105 a(a)(10)$ (1994) (repealed 1996)); IIRIRA $\$ 306(a)$, 110 Stat. at 3009607 (codified at 8 U.S.C.A. $\$ 1252(a)(2)(C)$ ) ("Notwithstanding any other proviston of law, no court shall have jurisdiction to review any final order of removal against any alten who is removable by reason of having committed [certain] criminal offense[s] . . ."); td.. 110 Stat. at $3009-612$ (codified at 8 U.S.C.A. $\S 1252(\mathrm{~g})$ ) (" $[\mathrm{N}]$ otwithstanding any other provision of law, no coun shall have junsdictson to hear any cause or claim by or on behalf of any alien arising from the decision or action by the Altomey General to commence proceedings, adjudicate cases, or execute removal orders against any alien under (his Act."); see also IIRIRA \& 306(b), 110 Stat. at 3009-612 (repealing 8 U.S.C. § 1105a). The relevant provisions of the AEDPA and the IIRIRA raise identical jurisdictional issues and. unless otherwise noted. will be treated interchangeably in this Note.

4. The federal government, however, has not yet argued that the acts eliminate all review, and tt concedes that the acts allow for review of "substantial constututional" clams. Sec Ramallo r. Reno, 114 F.3d 1210, 1214 (D.C. Cir. 1997); Mojica v. Reno, 970 F. Supp. 130. 157 (E.D.N.Y. 1997)

5. See Peter H. Schuck \& Theodore Hsien Wang. Contmity' and Change: Pattems of Immigration Litigation in the Courts, 1979-1990, 45 STAN. L. REv. 115, 167 (1992) (observing that. from 1989-1990. aliens succeeded in roughly $28 \%$ of cases in which they sought judicial review of final orders of deportation or exclusion); Anthony Lewis, The Rest Is Silence, N.Y. TIMES, Nov II. 1996, at AIS (attacking the elimination of judicial review in asylum proceedings and emphasizng the value of judicjal review to correct administrative errors).

6. See Frank H. Wu, The Limits of Borders: A Moderate Proposal for Immigranon Reform. STAN. L. \& POL'Y REV., Summer 1996, at 35, 51 (noting the "important cultural meaning" of providing judictal review of immigration decisions). 
of waivers of deportation under section 212(c) of the Immigration and Nationality Act (INA) ${ }^{7}$ for aliens convicted of certain criminal offenses ${ }^{8}$ applies retroactively. ${ }^{9}$ Prior to 1996 , aliens found deportable could apply for relief pursuant to section 212(c) of the INA, under which immigration judges took into account a variety of favorable elements in determining whether to grant a waiver of deportation. ${ }^{10}$ The retroactive elimination of section 212(c) relief would not only ensnare aliens convicted of minor crimes, ${ }^{11}$ but it would also negate their ties to, and accomplishments in, the United States. ${ }^{12}$ Moreover, while the jurisdictional provisions of the AEDPA target criminal aliens, numerous provisions of the IIRIRA apply to noncriminal aliens. Several district courts have already found that the IIRIRA narrows judicial review of the INS's denial of a noncriminal alien's attempt to stay deportation pending a motion to reconsider his deportation order. ${ }^{13}$ In addition, the IIRIRA seeks to eliminate judicial review over all denials of discretionary relief except asylum ${ }^{14}$ including denials of suspensions of deportation based on the alien's

7. Pub. L. No. $82-414, \S 212$ (c), 66 Stat. 163, 187 (1952) (codified as amended at 8 U.S.C. \& 1182(c)); see also Francis v. INS, 532 F.2d 268, 273 (2d Cir. 1976) (holding that section 212(c) relief is available in deportation as well as exclusion proceedings). The IIRIRA eliminated section 212(c) relief and replaced it with "cancellation of removal." IIRIRA § 304(b), 110 Stat. at 3009-594 to -596 (codified at 8 U.S.C.A. $\S 1229 \mathrm{~b})$.

8. The AEDPA bars section 212(c) relief to those convicted of: (1) an aggravated felony; (2) a controlled substance violation; (3) a firearm offense; (4) one of various "miscellaneous crimes"; or (5) two or more crimes involving "moral turpitude." AEDPA \$ 440(d), 110 Stat. at 1277 (amending 8 U.S.C. § 1182(c) (repealed 1996)).

9. In In re Soriano, No. A39186067, 1996 WL 426888 (B.I.A. June 27, 1996), the Attomey General vacated an earlier decision by the Bureau of Immigration Appeals (BIA) not to apply section 440 (d) of the AEDPA retroactively to pending section 212 (c) applications, and held instead that section 440 (d) applies retroactively to pending applications. See In re Soriano, No. 3289, Op. Att'y Gen. (Feb. 21, 1997).

10. Among the favorable elements considered by an immigration judge under section 212(c) wcre: family ties and duration of residence within the United States; evidence of hardship to the individual and family in the event of deportation; history of employment; service in the armed forces; service in the community; and other evidence attesting to an individual's good character and likelihood of future contributions to American society. See In re Marin, 16 I. \& N. Dec. 581, 584-85 (B.I.A. 1978).

11. See Mojica v. Reno, 970 F. Supp. 130, 137 (E.D.N.Y. 1997) (noting that the retroactive application of the AEDPA would require deportation of a legal permanent resident convicted of two misdemcanor offenses such as evading the fare on the New York City transportation system).

12. See Katherine Brady \& Dan Kesselbrenner, Recent Developments in the Immigration Consequences of Crimes, IMMIGR. NEwSL. (National Immigration Project of the Nat'l Lawyers Guild, Inc., Boston), Feb. 1997, at 3, 4 (arguing that the retroactive application of the AEDPA's elimination of section 212(c) relicf "is a serious blow to long-term permanent residents who make significant contributions to life in the United States and have deep roots in this country"); Mirta Ojito, Old Crime Returns To Haunt an Immigrant, N.Y. TIMES, Oct. 15, 1997, at B1 (discussing the threatened deportation of a legal permanent resident convicted of statutory rape in 1974 for having sex with his 15-year-old girlfriend, and noting the dismay of the defendant's wife and children and the family of his onetime girlfriend about his threatened deportation).

13. See, e.g., Moore v. District Dir., INS, 956 F. Supp. 878, 882 (D. Neb. 1997) (holding that the 1996 acts limit the scope of review over stays of deportation to instances where a petitioner " "can identify a grave constitutional error or a fundamental miscarriage of justice in [her] deportation proceedings"' (quoting Powell v. Jennifer, 937 F. Supp. 1245, 1252-53 (E.D. Mich. 1996))); see also Charan v. Schiltgen, No. C96-3061 FMS, 1997 WL 135938, at *4-5 (N.D. Cal. Mar. 18, 1997) (holding that the IIRIRA narrowly circumscribes the court's jurisdiction to review stays of deportation), amended 1997 WL 168495 (N.D. Cal. Mar. 31, 1997) (holding that the IIRIRA was not effective until April 1, 1997).

14. See infra note 242 and accompanying text. 
continuous physical presence in the United States, his good moral character, and the degree of hardship that would result from deportation. ${ }^{\text {is }}$

As an initial matter, courts have addressed whether the acts eliminate all statutory jurisdiction over final orders of deportation. In the first wave of cases, courts of appeals unanimously held that the AEDPA eliminated their jurisdiction to review deportation orders directly under the preexisting petitionfor-review scheme established by the Immigration and Nationality Act of $1961 .^{16}$ Several courts emphasized that the AEDPA did not raise a constitutional issue because other avenues of review remained available, ${ }^{17}$ while other courts did not address the constitutional issues raised by the Act. ${ }^{18}$

Subsequently, numerous legal permanent residents sought judicial review of their deportation orders by filing habeas actions in federal district courts. ${ }^{19}$ The district courts have adopted a two-step inquiry. First, they determine whether, as a matter of statutory construction, the acts eliminated or narrowed the scope of review under the general habeas statute of 28 U.S.C. $\$ 2241 .^{20}$

15. See Pilch v. INS, 129 F.3d 969 (7th Cir. 1997) (holding that the IIRIRA elımınates judictal review over discretionary denials of suspensions of deporation). But see Kalaw v. INS, 133 F.3d 1147. 1150-52 (9th Cir. 1997) (holding that the IIRIRA does not climinate judicial review over nondiscreltonary determinations of eligibility for suspension of deportation, and declining to address the scope of habeas corpus review); Tefel v. Reno, 972 F. Supp. 608, 614 (S.D. Fla. 1997) (suggesung that interpreung the IIRIRA to bar all judicial review over denials of suspensions of deportation would "raise serious constitutional issues").

16. See, e.g., Kolster v. INS, 101 F.3d 785 (Ist C.r. 1996). In 1961. Congress enabled aliens to challenge deportation orders by a "petition for review" directly to a court of appeals. Immigratuon and Nationality Act of 1961, Pub. L. No. 87-301. \$106(a). 75 Stat. 650,651 (codified at 8 U.S.C. $\$ 1105 a$ (1994) (repealed 1996)); see also Foti v. INS, 375 U.S. 217. 224-25 (1963) (stating that the intent of the 1961 act was to streamline the deporation process by vestung review in courts of appeals). This replaced the procedure established by the 1952 Immigration Act, which enabled aliens to challenge deportation orders through an action for declaratory relief under the Administratuve Procedure Act. See Shaughnessy v. Pedreiro, 349 U.S. 48, $51-52$ (1955). Prior to 1952, the sole procedure for challenging deportation orders was by a habeas corpus action in district court. See Mojica. 970 F. Supp. at 158 (citing Heıkkila v. Barber. 345 U.S. 229,235 (1953)).

17. See Kolster, 101 F.3d at 786 ("[A]t least the habeas revew provided by the Constutution remans available . . . "); Salazar-Haro v. INS, 95 F.3d 309. 311 (3d Cir. 1996) ("IW]e do nol foreclose judicial review of all claims by aliens arising in the course of deportation proceedings."), cert. dened. $117 \mathrm{~S}$. $\mathrm{Ct}$. 1842 (1997). One cour of appeals denied, in dieta, that habeas jurisdiction remaned under the general habeas statute of 28 U.S.C. $\$ 2241$ (1994). See Yang v. INS, 109 F.3d 1185. $1195-96$ (7th Cir. 1997). cert. denied, 118 S. Ct. 624 (1997). The Seventh Circuit, however, has since retreated from the view expressed in Yang. See, e.g., Turkhan v. INS, 123 F.3d 487, 490 (7th Cir. 1997) (holding that the AEDPA did not foreclose judicial review under either $\$ 2241$ or the Suspension Clause of the U.S. Constitution).

18. See, e.g., Duldulao v. INS. 90 F.3d 396. 400 n.4 (9th Cir. 1996) (leaving open the "avallability and scope of collateral habeas review"); Mendez-Rosas v. INS. 87 F.3d 672. 675-76 (5ih Cir. 1996).

19. Although most challenges to deportation orders were brought directly before the courts of appeals after Congress established the petition-for-review scheme in 1961. see supra note 16, aliens could still seek review in district court under the general habeas statute, see 28 U.S.C. $\$ 2241$; Orozco v. INS. 911 F.2d 539, 541 (11th Cir. 1990) ("Challenges to deportation proceedings are cognizable under 28 U.S.C. \$ 2241."). But see Daneshvar v. Chauvin, 644 F.2d 1248. 1251 (8th Cir. 1981) (limung habeas corpus to review the "denial of discretionary relief where deportability itself is not an issue").

20. Section 2241 is the general grant of habeas jurisdiction to federal courts and provides jurisdiction to consider petitions claiming that an individual is "in custody in violation of the Constutution or laws ... of the United States," 28 U.S.C. $\$ 224 /($ c)(3), or "in custody under or by color of the authonty of the United States," id. $\$ 224$ l(c)(1). 
If so, they then determine whether the acts violate the Suspension Clause of the U.S. Constitution, which provides that "[t]he privilege of the Writ of Habeas Corpus shall not be suspended, unless when in Cases of Rebellion or Invasion the public Safety may require it.".21

Virtually all courts have held that they retain habeas jurisdiction under the general habeas statute, ${ }^{22}$ but have disagreed as to whether the acts altered the scope of review. ${ }^{23}$ Courts that have construed the AEDPA and the IIRIRA as narrowing their jurisdiction under $\S 2241$ have nonetheless upheld the acts on the ground that they "preserve[] the balance between the Suspension Clause and Congress's plenary authority to control immigration."24 For example, in Mbiya v. INS, ${ }^{25}$ the district court defined the scope of review of deportation orders required by the Constitution by balancing the requirements of the Suspension Clause and Congress's plenary authority to control immigration. ${ }^{26}$ The Mbiya court adopted this balancing test, however, without providing either a satisfactory explanation for or a discussion of the writ, other than as a generic limitation on Congress's otherwise plenary power over immigration. First, the court relied on a statement by the Supreme Court in Heikkila v. Barber ${ }^{27}$ for the proposition that habeas review of deportation orders "'has always been limited to the enforcement of due process requirements." ${ }^{28}$ The Mbiya court, however, misunderstood the Court's statement in Heikkila ${ }^{29}$ and indeed, the case law belies the notion that habeas has ever been limited to

21. U.S. CONST. art. I, $\$ 9, \mathrm{cl} .2$.

22. See, e.g., Mojica v. Reno, 970 F. Supp. 130, 157, 159 (E.D.N.Y. 1997); Yesil v. Reno, 958 F. Supp. 828, 837 (S.D.N.Y. 1997); Duldulao v. Reno, 958 F. Supp. 476, 479-80 (D. Haw. 1997); Eltaycb v. Ingham, 950 F. Supp. 95, 98-99 (S.D.N.Y. 1997); Mbiya v. INS, 930 F. Supp. 609, 612 (N.D. Ga. 1996). But see Theck v. INS, No. C 96-4668 SI, 1997 WL 37565 (N.D. Cal. Jan. 14, 1997) (dismissing a habeas petition for lack of jurisdiction).

23. Compare Mojica, 970 F. Supp. at 157 ("The court retains subject matter jurisdiction under its general habeas corpus powers [over constitutional and nonconstitutional claims], which Congress did not intend to eliminate."), with Mbiya, $930 \mathrm{~F}$. Supp. at 612 (retaining jurisdiction to review only those final orders of deportation that "would result in a fundamental miscarriage of justice"). Other district courts have said that habeas jurisdiction exists at least over substantial constitutional claims, but have declined to decide the full scope of review because the petitioner had raised a substantial constitutional claim. See, e.g., Ozoanya v. Reno, 968 F. Supp. 1, 7 (D.D.C. 1997). Thus far, one court of appeals has decided this issue on habeas. See Goncalves v. Reno, 1998 WL 236799, at * 16 (1st Cir. May 15, 1998) (retaining jurisdiction under section 2241 to review "the pure statutory question" of whether the AEDPA's elimination of section 212(c) waivers applies retroactively).

24. Mbiya, 930 F. Supp. at 612 (interpreting the AEDPA); accord Eltayeb, 950 F. Supp. at 100.

25. 930 F. Supp. 609.

26. See id. at 612 .

27. 345 U.S. 229 (1953).

28. Mbiya, 930 F. Supp. at 612 (quoting Heikkila, 345 U.S. at 235).

29. The Court's reference to "due process" related to the scope of review on habeas of an agencys factual determinations. See Heikkila, 345 U.S. at 236 (differentiating the scope of review required by the Constitution from the review of factual determinations under the Administrative Procedure Act). Moreover, Justice Clark, the author of Heikkila, utilized the term "due process" to refer generally to statutory and regulatory requirements. See Henry M. Hart, Jr., The Power of Congress To Limit the Jurisdiction of Federal Courts: An Exercise in Dialectic, 66 HARv. L. REv. 1362, 1393 n.93 (1953). Justice Clark's use of the term "due process" in Heikkila should not, therefore, be misconstrued to imply that the Constitution requires habeas review solely of Fifth Amendment Due Process Clause claims. 
enforcing Fifth Amendment due process requirements in the deportation context. $^{30}$ The court then applied a balancing test similar to that used in Mathews v. Eldridge ${ }^{31}$ to determine the scope of the constitutional writ. ${ }^{32}$ Weighing the private interest (an individual's right to habeas corpus) against the government interest (Congress's plenary power over immigration), it determined that a "fundamental miscarriage of justice" standard should apply to habeas decisions in immigration. ${ }^{33}$ The Mbiya court, however, failed not only to include the third element of the Mathews balancing test, the risk of erroneous decision and probable value of additional procedural safeguards, ${ }^{34}$ but also to explain why the Suspension Clause should be collapsed into a balancing test in which the dominant component is the judicially created plenary power doctrine.

The Seventh Circuit's opinion in Yang $v$ INS ${ }^{35}$ exemplifies a second approach taken by courts reviewing the acts. The court relied on past Supreme Court deportation cases to assert, in dictum, that the Suspension Clause does not encompass review of discretionary decisions or errors of law in deportation proceedings. ${ }^{36}$ The Yang court's use of these cases, however, is both questionable and misleading. ${ }^{37}$ Numerous cases demonstrate that the Supreme Court has reviewed deportation orders under the Suspension Clause not only

30. Numerous cases reviewed under the 1891 and 1917 acts-which the Heikkilo Coun sand had made immigration decisions "nonreviewable to the fullest extent possible under the Constitution," $345 \mathrm{US}$ at 234-demonstrate review of a range of nonconstitutional claims. See infra notes $38-90$ and accompanying text. Moreover, after Heikkila, the Coun exereised habeas review of deportation orders under the 1891 and 1917 acts over claims of statutory construction and denial of discretionary relief See cases cited infra note 39.

31. 424 U.S. $319,334-35$ (1976) (establishing a balancing test under a due process analy sts that weighs the private interest affected by the official action; the risk of erroneous deprivation of such interest through procedures used and the probable value, if any, of additional safeguards; and the govemment interest. including the function involved and the physical and adminstrative burden).

32. See Mbiya, 930 F. Supp. at 612.

33. Id. at 613 .

34. See Mathews, 424 U.S. at 343.

35. 109 F.3d 1185 (7th Cir.), cert. dened, 118 S. Cl. 624 (1997). Yang was part of the first wave of cases in which cours of appeals reviewed the constitutionality of the 1996 acts on petitsons for review as opposed to habeas corpus.

36. See id. at 1195. For its position that the Suspension Clause does not extend to discretronary deportation decisions, the coun relied on Vajtauer v Commissioner of Immigrallon, 373 L'S 103 (1927). and United States ex rel. Tisi v Tod, 264 U.S. 131 (1924). For its position that the Suspension Clause does not extend to errors of federal law, it relied on Unired States v Cacers. 440 U.S $7+1$ (1979) Sete Yang. 109 F.3d at 1195.

Because the case was before the court on a petition for review there was no need to reach the issue of the scope of habeas review Instead, the coun could have done what even other coun of appeals had done: dismiss for lack of jurisdiction without reaching the scope of habeas review Sec supra notes 17-18 and accompanyingtext. Indeed, the Seventh Circuit did just that in (wo subsequent petition-for-review cases under the 1996 acts. See Turkhan v. INS, 123 F.3d 487.490 (7th Cir. 1997); Chow v INS. 113 F 3d 659. 669-70 (7th Cir. 1997).

37. At most, both Vajtauer and Tisi stand for the proposition that habeas offers limited review of factual determinations. See Vajlauer. 373 U.S. at 106: Tist. 264 U S. at 132-33 In fact, in Vaplauer, the Court suggested that only those factual findings supported by "some evidence" would not be reviewed 373 U.S. at 106. Caceres, meanwhile, was not an immigration case. but rather a determination about the use of the exclusionary rule in the criminal context. See Caceres, 440 U S at 754 
for constitutional claims, but also for legal error, ${ }^{38}$ abuses of discretion, ${ }^{39}$ and factual findings not supported by any evidence. ${ }^{40}$

Although the Supreme Court has recognized Congress's plenary power over substantive immigration decisions, ${ }^{41}$ it has maintained that this power is "subject to judicial intervention under the "paramount law of the Constitution" "42 and that it therefore does not trump the requirements of the Suspension Clause, the Fifth Amendment Due Process Clause, ${ }^{43}$ or the constitutionally mandated separation of powers. ${ }^{44}$ Thus, despite past efforts by Congress to confer "finality" over administrative deportation orders, ${ }^{45}$ habeas corpus has always been available to aliens to test the legality of those orders before an Article III court. ${ }^{46}$

38. See, e.g., Delgadillo v. Carmichael, 332 U.S. 388, 390-91 (1947) (rejecting the government's interpretation of "entry"); Gegiow v. Uhl, 239 U.S. 3, 8-10 (1915) (rejecting the govemment's broad interpretation of a public charge exclusion provision).

39. See, e.g., United States ex rel. Hintopoulos v. Shaughnessy, 353 U.S. 72, 77-79 (1957) (describing how in cases decided prior to the Immigration Act of 1952, courts reviewed whether the "correct legal standards" were applied in determining whether the petitioner was eligible for discretionary relicf and then exercised review over the agency's denial of discretion); United States ex rel. Accardi v. Shaughnessy, 347 U.S. 260,268 (1954) (reversing a denial of discretionary relief because the agency had exercised its discretion in a manner inconsistent with "existing valid regulations").

40. See Vajtauer, 373 U.S. at 106; see also United States ex rel. Kettunen, 79 F.2d 315, 317 (2d Cir. 1935) (requiring more than a mere "scintilla of evidence"); Lisotta v. United States, 3 F.2d 108, 111 (5th Cir. 1924) (requiring that the order of deportation be supported by "substantial evidence").

While a full discussion of the Suspension Clause deportation cases discussed here and supra notes 38-39 is beyond the scope of this Note, it is at least clear that the Yang dictum is not dispositive.

41. Congress's plenary power to exclude aliens, first recognized in the Chinese Exclusion Case, 130 U.S. 581, 606, 609 (1889), was extended to include the power to deport aliens in Fong Yue Ting v. United States, 149 U.S. 698, 707 (1893).

42. Carlson v. Landon, 342 U.S. 524, 537 (1952) (quoting Fong Yue Ting, 149 U.S. at 713). See generally Louis Henkin, The Constitution and United States Sovereignty: A Century of Chinese Exclusion and Its Progeny, 100 HARV. L. REv. 853, 863 (1987) (arguing that even plenary power is subject to constitutional restraints).

43. See, e.g., The Japanese Immigrant Case, 189 U.S. 86, 100 (1903) (holding that "fundamental principles that inhere in 'due process of law"' cannot be disregarded in deportation proceedings); see also Note, The Constitutional Requirement of Judicial Review for Administrative Deportation Decisions, 110 HARV. L. REV. 1850, 1867 (1997) (arguing that despite Congress's plenary power over immignation, the Due Process Clause and Article III require judicial review "at least for all nonfrivolous claims of unconstitutional action by the executive branch").

44. See INS v. Chadha, 462 U.S. 919, 940-41 (1983) (stating that Congress's plenary authority over immigration does not insulate it from judicial scrutiny under the Constitution's separation-of-powers requirement).

45. See, e.g., Act of Feb. 5, 1917, ch. 29, § 19(a), 39 Stat. 874, 889 (repealed 1952) (attempting to make final the Attomey General's decision to deport an alien).

46. See Heikkila v. Barber, 345 U.S. 229 (1953). In Heikkila, the Court observed that in both the 1891 and 1917 Immigration Acts, which governed until 1952, "Congress had intended to make these administrative [immigration] decisions nonreviewable to the fullest extent possible under the Constitution." Id. at 234 (emphasis added). Nonetheless, the Court also explained that courts had entertained habcas petitions during that period to review the legality of deportation and exclusion orders. See id. at 235 ("Now, as before, [an alien] may attack a deportation order only by habeas corpus."). Given that the courts continued to review habeas petitions during those years in which review was not authorized by statute, the Constitution therefore requires some habeas review of deportation orders. See Trevor Morrison, Notc, Removed from the Constitution? Deportable Aliens' Access to Habeas Corpus Under the New Immigration Legislation, 35 Colum. J. TRANSNAT'L L. 697, 701 (1997) ('There has therefore been an implicit recognition [by the Supreme Court] that access to habeas corpus for review of deportation orders must be preserved."); see also Chin Yow v. United States, 208 U.S. 8, 12 (1908) (Holmes, J.) (stating that, when 
Determining the full scope of review guaranteed by the Suspension Clause may at first seem a difficult task. ${ }^{47}$ In part, this is because the existence of statutory habeas jurisdiction for claims of federal prisoners since the Judiciary Act of $1789,,^{48}$ the direct ancestor of $\S 2241$, has obviated the need for the Supreme Court to engage in a sustained analysis of the constitutional writ. As a result of this difficulty, this Note returns to first principles to examine the availability and scope of judicial review guaranteed by the Suspension Clause to aliens facing deportation. Based on the Court's limited Suspension Clause jurisprudence and the history of the common law writ, it concludes that the constitutional writ not only applies to aliens facing deportation, ${ }^{49}$ but also supports a broad scope of review over deportation orders, encompassing both constitutional and nonconstitutional claims.

Part I examines the Supreme Court's view of the relationship between the common law writ of habeas corpus and the Suspension Clause. It also discusses the Court's understanding of the purported common law rule that the writ serves only to test the jurisdiction of the committing court, ${ }^{50}$ and the

faced with the illegal exclusion of an alien, "something must be done, and it naturally falls to be done by the courts"); Lisotta v. United States, 3 F.2d 108. 110 (5th Cir. 1924) (declanng that habeas must be available to review abuses of power and discretion by administratuve officers): THOMAS ALEXANDER ALEINIKOFF \& DAVID A. MARTIN, IMMIGRATION: PROCESS AND POLICY 857 (2d ed. 1991) (contending that the "brute requirements of the process of deporation and exclusion" have enabled courts to assume jurisdiction in the absence of any specific statutory authonzation). See generally Judith Resnik. Tiers. 57 S. CAL. L. REV. 837, 874 (1984) ("A premise of the 'Great Wni' is a willingness to look anew.").

47. See ALEINIKOFF \& MARTIN, supra note 46, at 857 n.6 (suggesting that specificatuon of the content of the constitutional writ "would not be easy").

48. Ch. 20, § 14, 1 Stat. 73,81 (codified as amended at 28 U.S.C. $\$ 2241$ (1994)).

49. This Note addresses only depontation, not exclusion. Pnor to 1996, deportation proceedings, in which the government sought to expel an alien who had already entered the United Stales, were distinguished from exclusion proceedings, in which the government sought to exclude an alien who had not yet entered the country. See generally ALEINIKOFF \& MARTIN, supra note 46, at 308-11. 476-78 (discussing exclusion and deportation, respectively). The IIRIRA combined exclusion and deportation proceedings into one forum, known as removal procoedings, as of April 1. 1997. See IIRIRA, Pub. L. No. 104-208, § 304, 110 Stat. 3009-546, $3009-589$ (1996) (codified at 8 U.S.C.A. \$ 1229a (Wesi Supp. 1997)) This Note, however, treats deportation separately, as does all litigation under the 1996 acts.

The Supreme Court has afforded aliens facing deportation-even illegal immigrants-greater constitutional protection than those facing exclusion. Compare The Japanese Immigrani Case. 189 U.S. 86. 100 (1903) (stating that the "fundamental principles that inhere in 'due process of law" cannol be disregarded in deportation proceedings), with Knauff v. Shaughnessy. 338 U.S. S37, S4t (1950) ("Whatever the procedure authorized by Congress is, it is due process as far as an alien denied eniry is concemed.") Among aliens facing deportation, the greatest protection has been given to legal permanent residents, the targets of the judicial review provisions of the 1996 acts under discussion here. While legal permanent residents facing deportation thus have the strongest claim to a broad scope of judicial review, this Note does not distinguish between legal permanent residents and illegal immigrants in terms of the scope of review required by the Suspension Clause.

50. See, e.g., Frank v. Magnum, 237 U.S. 309, 330-31 (1915) (emphasizung the "bare legal review that seems to have been the limit of judicial authority under the common-law pracuce, and under the [Habeas Corpus Act of 1679]"); Ex parte Watkins, 28 U.S. (3 Pet.) 193, 202-03 (1830) ("The judgment of a court of record whose jurisdiction is final, is as conclusive on all the world as the judgment of this coun would be."); Paul M. Bator, Finaliny in Criminal Law and Federal Habeas Corpus for State Prisoners. 76 Harv L. REV. 441, 466 (1963) (observing the Supreme Court's acceptance of the "black-letter pnneiple of the common law" that the writ was unavailable to review convictions by a court of competent junsdiction). But see 1 James L. Liebman \& Randy Hertz, Federal habeas Corpus Practice and Procedure $37-38$ (2d ed. 1994) (observing that in most of the federal habeas cases decided under the Judiciary Act of 1789. 
related rule of the incontrovertibility of the truth of the return. ${ }^{51}$ Part II demonstrates the common law writ's applicability to noncriminal detentions generally and to aliens in particular. It then explores the scope of review that courts exercised in noncriminal habeas cases and cases of summary criminal convictions at common law. Part III reexamines the 1996 legislation in light of the common law writ as constitutionalized in the Suspension Clause and explains why the writ compels a broad scope of review over deportation orders today.

\section{The Supreme Court, the Suspension Clause, AND THE COMMON LAW WRIT OF HABEAS CORPUS}

It is well established that the common law history of habeas corpus is integral to the Suspension Clause. In fact, the writ's importance and use in the United States predate the Constitution, as the early colonists "laid claim to [the writ] as one of the rights due them as Englishmen." directly addressed the scope and nature of the writ in Ex parte Bollman. ${ }^{33}$ In that case, Chief Justice Marshall unequivocally declared that "for the meaning of the term habeas corpus, resort may unquestionably be had to the common law." Similarly, in more recent cases expanding the range of claims

the Court's review was not limited to jurisdictional claims).

51. Cf. Frank, 237 U.S. at 330-31 (noting that "bare legal review ... seems to have been the limit of judicial authority [on habeas review] under the common-law practice"); id. (contrasting that with the more modem practice, as expanded by statute, in which the petitioner testifies as to "the truth of the matter respecting the causes of his detention, and the court, upon determining the actual facts, is to dispose of the party as law and justice require" (internal quotation omitted)). At common law, "no one can in any Case controvert the Truth of the [facts of the] Return to Habeas Corpus, or plead or suggest any Matter repugnant to it." 2 WiLliam Hawkins, A TREATISE OF THE Pleas OF tHE CROWN 113 (Garland Publ'g, Inc. 1978) (1721). When a court issued a writ of habeas corpus, the person having custody of the detaince was required to produce before the reviewing court the cause of commitment and, depending on the circumstances, the body itself. The production of the cause of commitment, along with the body in appropriate cases, by the person having custody of the detainee-normally the jailer-was known as "the retum." See generally WiLliam S. CHURCH, A TREATISE OF THE WRIT OF HABEAS CORPUS 186-262 (San Francisco, Bancroft-Whitney Co. 2d ed. 1893) (discussing the common law procedure governing the return to a writ of habeas corpus).

52. LARRY W. YACKLE, POSTCONVICTION REMEDIES 13 (1981).

53. 8 U.S. (4 Cranch) 75 (1807).

54. Id. at 93-94; see also Watkins, 28 U.S. (3 Pet.) at 201-02 (stating that to interpret the writ of habeas corpus provided in the Constitution, it is necessary to "inquir[e] into [the writ's] use, according to that law which is in so considerable degree incorporated into our own").

In Bollman, Marshall also suggested that the writ's existence was wholly a function of statute and that federal courts possessed no common law authority to issue the writ. See 8 U.S. (4 Cranch) at 93. To avoid the implication of a de facto suspension of the writ through nonauthorization, however, Marshall said that the habeas jurisdiction provided by section 14 of the Judiciary Act of 1789 demonstrated that Congress "must have felt, with peculiar force, the obligation of providing efficient means by which this great constitutional privilege should receive life and activity." Id. at 95 .

The Court has not spoken directly on whether Congress may eliminate all habeas jurisdiction under the Suspension Clause. The issue has provoked a lively and wide-ranging debate among scholars. Compare, e.g., LAURENCE H. TRIBE, AMERICAN CONSTITUTIONAL LAW \& 3-5, at 43 n.5 (2d ed. 1988) ("Absent congressional authorization, federal courts even lack power to issue writs of habeas corpus."), with Francis Paschal, The Constitution and Habeas Corpus, 1970 DUKE L.J. 605, 607 (arguing that congressional 
cognizable on habeas, the Court has looked to the writ's use at common law. ${ }^{35}$ Thus, although its view of habeas has evolved over time, the Supreme Court has never wavered from the proposition that the Suspension Clause incorporates the common law writ of habeas corpus as it existed in $1789 .^{.6}$

The Court has consistently paid homage to the importance and value of habeas corpus historically; ${ }^{57}$ nevertheless, it has generally articulated a narrow view of the writ's scope at common law. Throughout most of the nation's history, the Court has adhered to the purported common law rules that the truth of a return to a writ of habeas corpus could not be controverted ${ }^{58}$ and that the writ served only to test the jurisdiction of the sentencing courr. ${ }^{59}$ In essence, therefore, the Court believed that at common law habeas corpus was not a means by which to challenge criminal convictions. ${ }^{60}$

In the early 1960s, however, the Cour's expansive interpretation of habeas statutes sparked a revision of its view regarding the writ's scope at common

authorization is not essential because the "Constitution's habeas corpus clause is a directive to all superior courts of record, state as well as federal, to make the habeas privilege routinely available"). See generally Hart, supra note 29, at 1365 (suggesting that Congress cannot make exceptions to the Supreme Courn's appellate jurisdiction that would "destroy [its] essential role . . . in the constitutional plan"). I side with those scholars who argue that Congress could not eliminate all federal habeas jurisdiction.

55. See, e.g., Jones v. Cunningham, 371 U.S. 236, 238-40 (1963) (looking to the "common-law usages and history of habeas corpus" in holding that paroled prisoners meet the "in custody" requirement of the federal habeas statute).

56. See, e.g., Swain v. Pressley, 430 U.S. 372, 384 (1977) (Burger. C.J., concurnng) ("The sweep of the Suspension Clause must be measured by reference to the intention of the Framers and their understanding of what the writ of habeas corpus meant at the time the Constitution was drafted."): United States v. Hayman, 342 U.S. 205, 210 (1952) ("Since [the First] Congress had not defined the term "habeas corpus,' resort to the common law was necessary."); Henry J. Friendly. Is Innocence Irrelevant?: Collateral Attack on Criminal Judgments, 38 U. CHI. L. REv. 142, 170 (1970) ("It can scarcely be doubted that the writ protected by the suspension clause is the writ as known to the framers . . . ."); see also Micleskey v. Zant, 499 U.S. 467, 477 (1991) (stating that initially the "English common law defined the substantuve scope of the writ," prior to its subsequent expansion by statute).

In fact, the Court has suggested that, at least in the criminal context, the Suspension Clause may protect a more expansive form of the writ than that which existed in 1789, through statutory enactment and judicial elaboration of common law principles. See, e.g., Pressley, 430 U.S. at 380 n.13 (suggestung indirectly that Congress may not be able to "totally repeal all post-18th century developments in this area of the law," but declining to address the issue); Schneckloth v. Bustamonte, 412 U.S. 218, 256 (1973) (Powell, J., concurring) (suggesting that the Cour could not be "imprisoned by every particular of habeas corpus as it existed in the late 18th and 19th centuries"); Developments in the Law-Federal Habeas Corpus, 83 HARV. L. REV. 1038, 1269 (1970) ("While the framers probably could not have foreseen the extent to which the writ's function would expand, the history of two centuries of expansion through a combination of statutory and judicial innovation in England must have led them to understand habeas corpus as an inherently elastic concept not bound to its 1789 form." (footnote omitted)): see also Felker v. Turpin, 116 S. Ct. 2333, 2239-40 (1996) (assuming. arguendo, that the Suspension Clause refers to the writ as it exists today, rather than to the more limited form of the writ that existed in 1789).

57. See, e.g., Withrow v. Williams, 507 U.S. 680. $697-98$ (1993) (O'Connor. J., concurnng in part and dissenting in part) (stating that "'[habeas corpus] is today, as it has always been, a fundamental safeguard against unlawful custody"' (quoting Fay v. Noia, 372 U.S. 391.49 (1963) (Harlan. J., dissenting))): Bowen v. Johnston, 306 U.S. 19. 26 (1939) ("[T]here is no higher duty than to maintain [the wnt of habeas corpus] unimpaired.").

58. See supra note 51 and accompanying text.

59. See supra note 50 and accompanying text.

60. See, e.g., McNally v. Hill, 293 U.S. 131. $137-38$ (1934) (statung that the English authoritues before 1789 showed no instances of the writ's use to overtum crimınal convictuons). 
law. Writing for the Court in Fay v. Noia, ${ }^{61}$ Justice Brennan rejected the notion that "until recently the writ was available only in a very narrow class of lawless imprisonments." 62 Instead, he argued that habeas extended to the following: "judicial as well as executive restraints"; 63 inquiries beyond the "jurisdiction, in a narrow sense, of the committing court"; 44 "persons detained by order of inferior courts"; 65 and, more generally, "to remedy any kind of governmental restraint contrary to fundamental law." Justice Brennan's argument rested on a statement in Bacon's Abridgment, ${ }^{67}$ several contempt cases, ${ }^{68}$ and, above all, Chief Justice Vaughan's opinion in Bushell's Case. ${ }^{69}$

Justice Brennan's historical analysis, though, has not withstood the test of time. ${ }^{70}$ In an important and influential article written three years after Fay $v$. Noia was decided, Dallin Oaks argued that the common law writ provided neither de novo review of the factual findings of a superior court of record, nor a means of redressing every kind of "intolerable restraint" or "violation of fundamental law." from which Justice Brennan derived his "fundamental law" test did not concern the scope of habeas review, but rather whether the Court of Common Pleas had the power to issue the writ on behalf of a person imprisoned by another court where there was no issue of privilege, ${ }^{72}$ which would have meant that the petitioner was exempt from the jurisdiction of the sentencing court. ${ }^{73}$ In

61. 372 U.S. 391 (1963).

62. Id. at 402-03; cf. Townsend v. Sain, 372 U.S. 293, 311 (1963) (discussing the "common law understanding" of de novo review of factual findings on habeas).

63. Fay, 372 U.S. at 403.

64. Id. at 404.

65. Id. at 403 .

66. Id. at 405 .

67. See id. (" "[I]f the commitment be against law, as being made by one who had no jurisdiction of the cause, or for a matter for which by law which no man ought to be punished, the court are [sic] to discharge him." (quoting BACON'S ABRIDGMENT B.10 (John Bouvier ed., Philadelphia, T \& J.W. Johnson 1856) (emphasis added))).

68. See id. at 403 n.11.

69. 124 Eng. Rep. 1006 (C.P. 1670). Bushell's Case involved the commitment of a juror for contempt by the London Court of Sessions on the ground that he and his fellow jurors had acquitted certain defendants against the weight of the evidence. The Court of Common Pleas deemed the return to the writ of habeas corpus insufficient and discharged the prisoner. See id. at 1009. Vaughan subsequently stated that, as a matter of law, jurors could not be held in contempt for finding against the evidence. See id. at 1016. His decision, however, relied not on the insufficiency of the return, but on the court's power to go behind the retum to review the evidence itself. See id. at 1007 ("[O]ur judgment ought to be grounded upon our own inferences and understandings, and not upon theirs.").

70. See infra text accompanying notes 77-78.

71. Dallin H. Oaks, Legal History in the High Court-Habeas Corpus, 64 MICH. L. REv. 451, 457-58, 468 (1966); cf. Fay, 372 U.S. at 449 (Harlan, J., dissenting) (criticizing Justice Brennan's "square rejection of long-accepted principles governing the nature and scope of the Great Writ").

72. See Oaks, supra note 71 , at 463 \& n.71 (arguing that this controversy was not settled until the passage of the Habeas Corpus Act, 1679, 31 Car. 2, ch. 2 (Eng.), which gave the Court of Common Pleas independent jurisdiction to issue the writ in a criminal case). But see Maxwell Cohen, Habeas Corpus Cum Causa: The Emergence of Modern Writ (pts. 1 \& 2), 18 CAN. B. REv. 10, 179, 181 (1940) (noting the "wealth of precedents" supporting the decision of the Court of Common Pleas to issue the writ where no writ of privilege was involved).

73. See Edward Jenks, The Prerogative Writs in English Law, 32 YALE L.J. 523, 525 (1923). 
addition, Oaks challenged Justice Brennan's assertion that at common law "due process" implied "supervisory review of the acts of judges of superior courts, or a broad license to "remedy any kind of governmental restraint contrary to fundamental law." "74 Finally, Oaks pointed to Vaughan's own assertion that the broad power to review the sufficiency of the return applied only to persons committed for contempt, not to those committed for treason or felony. ${ }^{75}$ Similarly, the post-Warren Court's shift to a narrower interpretation of statutory habeas was accompanied by a movement away from Fay's expansive conception of the common law writ $^{76}$ and a return to the Court's earlier position that at common law the writ was not a means by which to challenge criminal convictions. Justice Brennan's view of the common law writ was explicitly rejected by three Justices in Schneckloth v. Bustamonte, ${ }^{n}$ while the Court's actual holding in Fay $v$. Noia has been substantially overruled by a series of decisions. ${ }^{78}$

Criticism of Fay v. Noia was not premised on the authority it bestowed on the common law writ as an interpretive device, but rather on its actual interpretation of the common law writ in the criminal context. Courts interpreting the 1996 acts have, nonetheless, posited the same narrow conception of common law writ habeas in noncriminal deportation cases. ${ }^{79}$

74. Oaks, supra note 71 , at 466 (quoting Fay, 372 U.S. at 405).

75. See id. Oaks cited the following passage in Bushell's Case:

[U]pon a general commitment for treason or felony. the prisoner (the cause appeanng) may press for his tryal,... and upon his indictment and tryal, the particular cause of his imprisonment must appear, which proving no treason or felony, the pnsoner shall have the benefit of it. But in this case [involving contempt]. though the evidence given were no full nor manifest evidence against the persons indicted, but such as the jury upon 11 ought to have acquitted those indicted, the prisoner shall never have any benefit of $\mathrm{H}$. but must contunue in prison, when remanded, until he hath paid that fine unjustly impos'd on hm. which was the whole end of his imprisonment.

Bushell's Case, 124 Eng. Rep. 1006, 1010 (C.P. 1670).

76. The last Supreme Court case to describe a broad scope for common law habeas mas decided in 1969, the same year Chief Justice Warren retired from the Court. See Hams v. Nelson. 394 U.S 286. 292 (1969) (stating that the "power of inquiry on federal habeas corpus is plenary"). For a namower view of the scope of the common law writ, see, for example. Swain v: Pressley, 430 U S 372.385 (1977) (Burger. C.J., concurring in part and concurring in the judgment), which asserted that "(a)t common law, the writ was available to (1) compel adherence to prescribed procedures in advance of tnal: (2) to inquire into the cause of commitment not pursuant to judicial process: and (3) to inquire whether a commutung coun had proper jurisdiction"; and Preiser v. Rodriguez, 411 U.S. 475, 485 (1973). which stated that habcas was originally limited to "determining simply whether or not the commutung coun had been possessed of jurisdiction."

77. 412 U.S. 218, 253-54 (1973) (Powell, J., joined by Burger, C.J., and Rehnquist, J , concumng)

78. See, e.g., Coleman v. Thompson, 501 U.S. 722. 749-50 (1991) (applying the "cause and prejudice" standard to a petitioner's failure to appeal a state court judgment): Wanwnght v. Sykes, 433 U S 72, 87 (1977) (applying the "cause and prejudice" standard to a petutioner's falure to object contemporaneously to the introduction of his confession at trial).

79. See, e.g., Charan v. Schiltgen, No. C 96-3061 FMS, 1997 WL 135938, at +4.5 (N D Cal Mar 18, 1997), modified on other grounds. 1997 WL 168495 (N.D. Cal. Mar. 31. 1997) The analysts in Churan demonstrates the extent to which the writ's use to review cnmınal convictions has come to dominate the field of habeas scholarship, as the court relied solely on cnminal cases in is analysis of the wni's traditional scope. See id. at *4. Likewise, distnct courts interpretung the 1996 acis hive seized on a "fundamental miscarriage of justice" standard, see supra lext accompanying note 33. imported directly from a line of criminal habeas cases, see, e.g., Murray v. Carner. 477 U.S. 478.495 (1986) (holding that in an 
Does the history of the Great Writ, the "highest remedy in law, for any man that is imprisoned," review? A searching analysis of the writ's history reveals a more complex story. ${ }^{81}$ The "black-letter" rule against controverting the return was not a hardand-fast rule in all criminal cases, and it did not take into account the broad scope of review exercised in noncriminal matters, instances of executive detention, or summary convictions. Even Oaks, a severe critic of the Supreme Court's use of habeas's history to justify federal post-conviction review of state court decisions, has recognized the writ's frequent use and the broad scope of review it provided at common law to challenge noncriminal confinement. ${ }^{82}$ As Part II demonstrates, the scope of common law habeas review of noncriminal confinement was indeed a different matter altogether. If, as the Court has maintained, constitutional habeas must be defined by referring to the writ at common law, Congress, however plenary its power over immigration, cannot gut the writ of its common law core without violating the Suspension Clause. ${ }^{83}$

\section{The Availability and Scope of Habeas Review at Common LaW}

This part first discusses the origins of the writ of habeas corpus. ${ }^{84}$ It then examines the writ's applicability to noncriminal cases in general and to aliens in particular. Next, it identifies the five factors that triggered a broad scope of review on habeas and the actual scope of review exercised at common law. ${ }^{85}$

"extraordinary case," in which a constitutional violation is coupled with factual innocence, a court may grant habeas relief absent a showing of "cause" for the petitioner's procedural default).

80. John Selden's Argument, Proceedings in Parliament Relating to the Liberty of the Subject, 3 Howell's State Trials 59, 95 (1628).

81. See generally Amnon Rubenstein, Habeas Corpus as a Means of Review, 27 MoD. L. REv. 322, 322 (1964) ("The plethora of English decisions on the subject is not very illuminating and attempts at elucidation are rarely made.").

82. See Oaks, supra note 71 , at 454 n.20.

83. Cf. United States ex rel. Marcello v. District Dir. of the INS, 634 F.2d 964, 971 (5th Cir. Jan. 1981) ("There can be no doubt that there exists a constitutional core of habeas corpus authority, derived from the Common Law, guarded by [the Suspension Clause], and proof against congressional or executive tampering save in the event of invasion or rebellion."); PETER W. LOW \& JOHN C. JEFFRIES, JR., FEDERAL COURTS AND THE LAW OF FEDERAL-STATE RELATIONS 68 n.a (3d ed. Supp. 1997) (arguing that the form of the writ used to challenge executive detention, as opposed to the form used to challenge the detention of convicted criminal offenders, was likely foremost in the minds of the Framers when they drafted the Suspension Clause).

84. Unless otherwise indicated, this Note refers to the writ of habeas corpus ad subjiciendum. The King's Bench developed this form of the writ in the 16th century, "chiefly to protect subjects against unconstitutional imprisonment by privy councillors and officers of state." J.H. BAKER, AN INTRODUCTION TO ENGLISH LEGAL HISTORY I26 (2d ed. 1979). By the late 17 th century, particularly after the passage of the Habeas Corpus Act of 1679, the writ ad subjiciendum became the primary safeguard against all illegal detention. See 9 WILLIAM HOLDSWORTH, A HISTORY OF ENGLISH LAW 117-18 (2d ed. 1938). While the Act's protections applied only to criminal matters, the common law form of the writ ad subjiciendum was used to challenge noncriminal confinement. See id. at 119; ROBERT S. WALKER, THE CONSTITUTIONAL, AND LEGAL DEVELOPMENT OF HABEAS CORPUS AS THE WRIT OF LIBERTY 82-83 (1960).

85. For the sake of clarity, this Note uses the terms "at common law," "common law history," and "common law habeas" to refer to the writ generally - that is, to English cases decided under both the 


\section{A. Origins of Habeas Corpus}

Prior to the sixteenth century, habeas corpus was used primarily by the central courts of the Crown to check the jurisdiction of local courts. ${ }^{86}$ Habeas corpus enabled the central courts to bring parties to proceedings in inferior courts before the common law courts, or to release a litigant in one of the central courts who had been arrested by the process of an inferior court. ${ }^{87}$ Habeas therefore provided a common remedy against the misuse of jurisdiction by borough courts; ${ }^{88}$ it also provided a powerful means by which common law courts could expand their jurisdiction at the expense of local courts. ${ }^{89}$ While this early use of habeas to defeat proceedings in inferior courts was certainly abused, ${ }^{90}$ it nonetheless suggests the writ's most fundamental attribute: testing the legality of the cause of commitment. ${ }^{91}$

Starting in the sixteenth century, habeas corpus was used to challenge the validity of imprisonments by rival central courts, such as the Cour of Requests, ${ }^{92}$ the Court of Admiralty, ${ }^{93}$ and the Court of High Commission. In part, this reflected Chief Justice Coke's struggle to transfer the supervision of both inferior courts and these quasi-judicial conciliar authorities-the supervision of which was traditionally a royal prerogative-to the King's Bench. ${ }^{95}$ Coke's belief in the supremacy of the common law and the superiority of the common law courts to all the other English courts eventually

various habeas corpus acts and the common law form of the writ. In contrast, "statutory habeas" refers to cases decided solely under those acts, whereas "common law wni" refers solely to the nonstatutory. common law form of the writ.

86. See R.J. SHARPE, THE LAW OF Habeas CoRpus 4-5 (1989).

87. See 9 HOLDSWORTH, supra note 84, at 109.

88. See BAKER, supra note 84 , at 126.

89. See 9 HOLDSWORTH, supra note 84 , at 109.

90. See Cohen, supra note 72, at 15 (describing legislatıon intended to curb such abuses).

91. See SHARPE, supra note 86 , at 5 .

92. See, e.g., Humfrey v. Humfrey, 135 Eng. Rep. 291 (C.P. 1572).

93. See, e.g., Hawkeridge's Case, 77 Eng. Rep. 1404. 1404 (C.P. 1616) (emphasizing the court's failure to specify elements of the offense or the cause of commitment); Thomlinson's Case. 77 Eng. Rep. 1379, 1379 (C.P. 1604) (emphasizing the court's failure to specify the cause of examunation in interrogatories).

94. See, e.g., Bradstone v. High Comm'n, 80 Eng. Rep. 1138 (K.B. 1613) (holding that the fallure to give alimony to one's wife was not a crime for which the Cour of High Commission could fine or imprison the defendant); Chancey's Case, 77 Eng. Rep. 1360 (K.B. 1611) (holding that the high commission could not fine or imprison the defendant for adultery): Roper's Case, 77 Eng. Rep. 1326 (K.B. 1607) (holding that the jurisdiction of the high commissioner did not extend to a debt owed to a vicar). This high ecclesiastical court was created by statute in 1588 and was given a wide junsdiction to "vindicale the peace and dignity of the church." 3 WILLIAM BLACKSTONE, COMMENTARIES -67-68. It was abolished by statute in 1640 . See id. at *68.

95. See EDWARD COKE, THE FOURTH PART OF THE INSTITUTES OF THE LAWS OF ENGLAND 71 (Garland Publ'g. Inc. 1979) (1644) (claiming that the King's Bench had jurisdiction to correct "errors and misdemeanors extrajudicial[ly], tending to the breach of the peace, or oppression of the subjects . . or any other manner of misgovernment"); see also BAKER, supra note 84, at 124-25 (discussing Coke's baltle against royal prerogative); Harold J. Berman, The Origins of Hisioncal Jurisprudence: Coke. Selden. Hale. 103 YALE L.J. 1651, 1674 (1994) (noting that Coke fought "stubbomly to limit the king's prerogatuve powers and to subject them to the common law and to parliamentary control"). 
prevailed ${ }^{96}$ even though Coke-despite his reputation as the greatest lawyer of his day-was dismissed from the King's Bench in 1616 after refusing to state that he would stay a suit on the King's order. ${ }^{97}$

This struggle had an important effect on the development of habeas corpus. While the writ was ostensibly limited to ensuring that the committing court had jurisdiction, it in fact ensured that power was exercised in conformity with controlling statutes and the common law. ${ }^{98}$ Moreover, as one scholar has noted, in the battle of superior courts "with these partially judicial, partially executive bodies, the writ moved yet closer to its role as a safeguard against the arbitrary power of the Crown itself." prerogative acts by councillors and conciliar courts, ${ }^{100}$ the writ, somewhat ironically, would later be associated with the King's effort to provide justice to any subject deprived of his liberty. ${ }^{101}$

\section{B. Availability of Habeas Corpus To Challenge Noncriminal Confinement and Its Applicability to Aliens}

Despite the long association between habeas corpus and criminal confinement, ${ }^{102}$ the writ was available at common law to challenge a broad range of noncriminal confinement, both public and private. ${ }^{103}$ Although statutory habeas was not extended to noncriminal detentions until 1816, ${ }^{104}$ it was well established that those confined for noncriminal matters had

96. See Berman, supra note 95 , at 1680 .

97. See BAKER, supra note 84 , at $144-45$.

98. See, e.g., Codd v. Turback, 81 Eng. Rep. 94 (K.B. 1615) (releasing a prisoner committed by the high commission for opprobrious words when the return failed to state what the words were and whether those words constituted an offense at common law).

99. William F. DUKER, A CONSTItUTIONAL History of HABEAS CORPUS 40 (1980).

100. See BAKER, supra note 84 , at 124.

101. See Bourn's Case, 79 Eng. Rep. 465, 465-66 (K.B. 1619) (explaining that it was in the nature of habeas corpus as a prerogative writ that the "King ought to have an account why any of his subjects are imprisoned").

102. In part, the link between habeas and criminal confinement is due to the celebrated Habeas Corpus Act of 1679, 31 Car. 2, ch. 2 (Eng.), which had a profound influence in America. See Paschal, supra notc 54, at 622 ("The prestige of the 1679 Act was so high that several states enacted almost word-for-word copies and others almost certainly regarded it as part of their common law.").

103. See, e.g., Goldswain's Case, 96 Eng. Rep. 711 (C.P. 1778) (challenging a sailor's impressment); R. v. Delaval, 97 Eng. Rep. 913 (K.B. 1763) (challenging the unlawful custody of a child); R. v. Turlington, 97 Eng. Rep. 741 (K.B. 1761) (challenging a woman's custody in a "private mad-house"); $R$. v. Nathan, 93 Eng. Rep. 914 (K.B. 1730) (applying habeas to a commitment by the bankruptcy commissioners); Lister's Case, 88 Eng. Rep. 17 (K.B. 1721) (applying habeas to a husband's unlawful detention of his wife); BAKER, supra note 84, at 127 (observing that the writ was not confined to those facing criminal charges); 9 HOLDSWORTH, supra note 84 , at 119 (noting the increasing use of habeas to gain relief from private and noncriminal confinement starting in the late 17th century); Cohen, supra note 72 , at 196 (noting that the original purpose of the writ was to challenge civil imprisonments).

104. See Habeas Corpus Act, 1816, 56 Geo. 3, ch. 100 (Eng.). The 1816 Act also abolished the rule against controverting the return in noncriminal matters, see id. \$\$ 3-4, except for those "imprisoned for Debt or by process in any civil Suit," $i d$. $\S 1$. It has been suggested that those committed for criminal matters also had recourse to the common law writ. See Brief of Professor Paul A. Freund for Respondent at 30-32, United States v. Hayman, 342 U.S. 205 (1952) (No. 23). 
recourse to the common law writ. ${ }^{105}$ Indeed, the common law writ had been used to test the legality of noncriminal custody since at least the early seventeenth century, ${ }^{106}$ and courts issued writs of habeas corpus in an array of noncriminal contexts. ${ }^{107}$ Moreover, in practice judges applied many of the procedural protections ${ }^{108}$ established for criminal cases by the celebrated Habeas Corpus Act of $1679^{109}$ to noncriminal matters. ${ }^{110}$

Although no exact analog to present immigration procedures existed at the time, it is clear that aliens could seek review of their confinement through the common law writ of habeas corpus:

In any matter involving the liberty of the subject the action of the Crown or its ministers or officials is subject to the supervision and control of the judges on habeas corpus. The judges owe a duty to safeguard the liberty of the subject not only to the subjects of the Crown, but also to all persons within the realm who are under the protection of the Crown ... and this whether they are alien friends or alien enemies. ${ }^{111}$

Indeed, the availability of habeas to aliens is consistent with the overall increase in aliens' legal rights in England during the sixteenth and seventeenth centuries. $^{112}$

105. See 6 ENCYCLOPEDIA OF THE LAWS OF ENGLAND 132 (A. Wood Renton ed., London, Sweet \& Maxwell LD. 1898) ("[T]he Habeas Corpus Act, 1679. applies only to cases of detention or impnsonment for criminal or supposed criminal offences... without in any way infringing on the common law jurisdiction of the Courts or judges." (emphasis added)). Although in nonenminal matters courts contunued to have discretion whether to grant writs of habeas corpus, they "seldom" refused to grant the wrnt. See WALKER, supra note 84 , at 80 .

106. See Cohen, supra note 72 , at 35 .

107. See cases cited supra note 103.

108. See 9 HolDSwORTH, supra note 84, at 118 (staung that the Act made the wnt the "most effectuve weapon yet devised for the protection of the liberty of the subject"). These protections required, inter alıa. a return to the writ within a specified time, delivery by jailers to prosoners of a true copy of the warrant of commitment, and either a trial for treason or felony at the nexi sessions or basl. wath an exicnsion for only one term allowed to the Crown. See id.; see also SHARPE, supra note 86, at 19 (statung that the 1679 Act was "largely a piecemeal repairing of the common law").

109. 31 Car. 2, ch. 2 (Eng.).

110. For example, even though they were not required to do so by the $1679 \mathrm{Act}$. judges generally issued the writ when not in session and made the writ retumable immediately in noneriminal malters. See 9 HOLDSWORTH, supra note 84, at 121.

111. 11 HaLSBURY's LawS OF ENGLANd 25 (3d ed. 1955) (footnotes omitted). Similarly. Blackstone described the writ as "efficacious . . . in all manner of illegal confinement," 3 BLACkstoNe, supra note 94, at *131 (emphasis added), while Coke said habeas extended to all detention "conira legem terrae, against the law of the land," I EDWARD COKE. THE SECOND PART OF THE INSTTIUTES OF THE LAWS OF ENGLAND 54 (William S. Hein Co. 1986) (1642 ed.). See also Eisentrager v. Forrestal, 174 F.2d $961,964$. 65 (D.C. Cir. 1949) (referring to the writ's application to aliens at common law): Mornson, supro note 46. at 714 (concluding that the "writ was not subject to special limitations when implicatung immugration or foreign relations").

112. See 9 HOLDSWORTH, supra note 84, at 94-97. In England, aliens can sull challenge thetr deportation orders through habeas corpus. See BAKER, supra note 84. at 127-28 (observing that the chicf use of habeas in 20th-century England is to question orders of extradition and deportatson). 
Thus, slaves gained release through the Great Writ, ${ }^{113}$ while other nonEnglishmen also gained review via habeas corpus of alleged deprivations of liberty. ${ }^{114}$ Aliens in the United States have likewise been able to challenge their confinement through habeas corpus since the nation's founding. ${ }^{115}$

\section{Elements Triggering a Broad Scope of Review on Habeas Corpus}

In challenging noncriminal confinement, as well as summary criminal convictions, the common law writ of habeas corpus was not limited simply to "jurisdictional" issues, but encompassed legal error, abuses of discretion, and, at times, factual findings. Indeed, the meaning of "jurisdiction" varied at common law, depending on the context. Although jurisdictional error was extremely narrow when it involved collateral review of a superior court judgment, the concept might have meant something "close[] to full review of the merits" when it involved review of an inferior court judgment. ${ }^{116}$ While there was no precise formula, the writ's scope was always broadest where the commitment involved one or more of the following five elements: (1) a threat to the subject's fundamental liberty; (2) the exercise of executive power; (3) a judgment by an inferior court; (4) no safeguard of jury trial; and (5) the lack of any other available remedy. I will discuss each in turn.

113. See, e.g., Sommersett's Case, 20 Howell's State Trials 1 (K.B. 1772) (Mansfield, C.J.) (releasing on habeas a slave from Africa who had been purchased in Virginia and brought to England, where slavery was illegal); Knight v. Wedderburn (Sess. 1775-1778) (Scot.) (releasing a slave from Africa on habeas), reprinted in Sommersett's Case, 20 Howell's State Trials at 1 n.*; see also Shaughnessy v. United States ex rel. Mezei, 345 U.S. 206, 219 (1953) (Jackson, J., dissenting) (referring to Sommersett's Case to illustrate that habeas corpus extended to aliens at common law).

114. See, e.g., Ex parte Hottentot Venus, 104 Eng. Rep. 344 (K.B. 1810) (entertaining a habcas petition of a "female native of South Africa" allegedly held in private custody); R. v. Schiever, 97 Eng. Rep. 551 (K.B. 1759) (reviewing, but denying, the habeas petition of a neutral alien deemed a prisoner of war because he was captured aboard an enemy French privateer).

Moreover, the Habeas Corpus Act of 1679, though limited to criminal matters, protected all inhabitants of England, including nonenemy aliens, from being sent abroad as prisoners without their consent. The Act provided that no inhabitant of England could be sent as a prisoner abroad, see 31 Car. 2 , ch. $2, \S 12$, except persons contracting, or convicts requesting, to be transported, and those having committed a capital offense in the place to which they were to be sent, see id. $\$ \S 13,14,16$. In fact, fear of being imprisoned overseas was a driving force behind the 1679 Act. See Cohen, supra note 72, at 186.

115. See, e.g., United States v. Villato, 2 U.S. (2 Dall.) 370, 373 (1797) (granting a habeas petition and ordering the release of a Spanish citizen accused of high treason). The fact that federal courts were statutorily authorized to review state custody of aliens 25 years prior to gaining habeas jurisdiction over citizens in state custody further demonstrates the unique and important role federal courts have played in reviewing habeas petitions of aliens. Compare Act of Aug. 29, 1842, ch. 257, 5 Stat. 539, 539-40 (codified as amended at 28 U.S.C. $\$ 2241$ (c)(4) (1994)) (authorizing federal habeas review in cases involving "subjects or citizens of a foreign State"), with Act of Feb. 5, 1867, ch. 28, $\$ 1,14$ Stat. 385, 385.86 (codified as amended at 28 U.S.C. $\$ 2241$ (c)(3)) (authorizing federal habeas review in cases of all persons restrained of their liberty "in violation of the constitution, or any treaty or law of the United States").

116. Ann Woolhandler, Demodeling Habeas, 45 STAN. L. REV. 575, 589 (1993); see also SHARPE, supra note 86 , at $25-26$ (discussing the broad scope of jurisdictional review of summary convictions). 


\section{Threat to Fundamental Liberty}

In noncriminal matters, common law courts were inclined to exercise a broad scope of review where the confinement presented a threat to the fundamental liberty of an individual. The broad construction given to a "fundamental liberty interest" is demonstrated by the range of claims cognizable on habeas at common law. ${ }^{17}$ As a prerogative writ, habeas corpus required an explanation for any deprivation of an individual's liberty. ${ }^{118}$ Courts thus recognized that liberty could be endangered not only by the state, but by private actors as well. ${ }^{119}$

\section{Exercise of Executive Power}

Executive detention implicated the core function of the writ of habeas corpus, and the writ entered its most important phase when it began to be used to challenge executive commitments in the late sixteenth century. ${ }^{120}$ In Searche's Case ${ }^{121}$ and Howel's Case, ${ }^{122}$ the writ was used to challenge the power of the Privy Council to imprison without cause. In the celebrated Darnel's Case, ${ }^{123}$ the writ was issued to challenge King Charles I's imprisonment of several subjects for refusing to contribute to a forced loan. Although the return was deemed satisfactory, the case sparked the Petition of Right, ${ }^{124}$ which established the principle that the King could not imprison by

117. See, e.g., Goldswain's Case, 96 Eng. Rep. 711 (C.P. 1778) (reviewing the Impressment of a sailor); Sommersett's Case, 20 Howell's State Trials at 82 (releasing a slave); Hetley v. Boyer, 79 Eng. Rep. 287 (K.B. 1613) (releasing an individual imprisoned by the Sewers Commission).

118. See, e.g., Boum's Case, 79 Eng. Rep. 465 (K.B. 1619); see also Codd v. Turback. 81 Eng. Rep. 94, 94 (K.B. 1615) (Coke, C.J.) ("By the law of god, none ought to be imprisoned, but with the cause expressed in the return of his imprisonment ....").

119. See, e.g., R. v. Turlington, 97 Eng. Rep. 741 (K.B. 1761) (revewing factual findings in a case involving the commitment of a woman to a "private mad-house"): Kıng v. Lec. 83 Eng. Rep. 482 (K.B. 1676) (reviewing factual findings on an application by a wife to determine whether her husband's "ill usage" and "imprisonment" of her was lawful, but refusing to release the wife).

120. See DUKER, supra note 99, at 40-48; see also Lonchar v. Thomas, 116 S. Cl. 1293, 1298 (1996) (stating that the common law writ's "most basic purpose [was] avoiding senous abuses of power by a govermment, say a king's imprisonment of an individual, w'thout referring the matter to a courr" (cmphasis added)); Swain v. Pressley, 430 U.S. 372, 385 (1977) (Burger. C. .. concurnng) (noung that at common law and at the time of the Framers, the writ was used "to inquire into the cause of commitment not pursuant to judicial process").

121. 74 Eng. Rep. 65 (C.P. 1587) (discharging a prisoner detained for arrestung a surety indirectly designated by the Queen to receive protection from arrest).

122. 74 Eng. Rep. 66 (C.P. 1587) (releasing a prisoner for insufficient cause stated in the retum).

123. 3 Howell's State Trials I (K.B. 1627). One judge called the case the grealest cause I ever knew in this court." Id. at 31 (Doderidge, J.). Damel's Case is also known as the Fwe Knights Case. See. e.g.. 6 PROCEEDINGS IN PARLIAMENT 1628: APPENDIXES AND INDEXES 36 (Mary Frear Kecler er al. eds.. 1983).

124. 3 Car., ch. 1 (1627); see also 9 HOLDSWORTH, supra note 84, at IIS; WALKER, supra note 84, at 73 (observing that the Petition "cemented in constitutuonal theory that no man ought to be depnved of his liberty without due course of law as administered by the ordinary tribunals of the land," and designated habeas corpus the "legal instrument" to ensure this "great purpose"). The common law wnt also played an important role in placing further limits on executive power. sparking the Habeas Corpus Act of 1640. 16 Car., ch. 10, \& 3, which abolished the Star Chamber and other conciliar courts. 
special command without showing cause. These politico-criminal cases thus underscore the following points: that any detention required cause or justification be provided; that the writ's primary purpose had become the protection of the liberty of individuals; and that the writ played a structural role in limiting executive power.

These cases, however, do not fully capture the scope of review in more ordinary cases. ${ }^{125}$ Moreover, one need not have been detained by a direct order of the King himself to fall within the meaning of "executive detention." The courts' review of impressment of sailors by the Admiralty reflected a "very notorious instance of judicial authority in matters most nearly concerning the executive." 126 In these cases, the courts exercised a broad scope of review on habeas. ${ }^{127}$ Similarly, commitments by quasi-executive agencies such as the Sewers Commission were subject to searching review on habeas corpus. ${ }^{128}$ While the birth of the administrative state is a phenomenon of the late nineteenth and twentieth centuries, ${ }^{129}$ at common law executive detentions-even by proto-agencies such as the Admiralty and the Sewers Commission-triggered a broad scope of review on habeas. ${ }^{130}$

\section{Judgment of an Inferior Court}

The distinction at common law between inferior and superior courts was an important one, ${ }^{131}$ and it significantly influenced the scope of review on habeas. Superior courts were courts of general jurisdiction, whereas inferior courts were limited in jurisdiction by area and power to those matters expressly delegated to them by the document authorizing their establishment

125. See Cohen, supra note 72 , at 172 (discussing the narrower scope of review over special commitments by the King or his Council). 1939).

126. A.V. Dicey, INTROduction to THE Study of the LAW OF THE CONSTITUTION 223 (9th ed.

127. See, e.8., Goldswain's Case, 96 Eng. Rep. 711 (C.P. 1778) (reviewing the facts surrounding a sailor's impressment).

128. See, e.g., Hetley v. Boyer, 79 Eng. Rep. 287 (K.B. 1613) (invalidating the Sewers Commission's taxation scheme). See generally Glen O. Robinson ET AL., The AdMINISTRATIVE PRocess 46 (4th ed. 1993) (discussing the history of using prerogative writs, such as habeas corpus, to gain review of inferior officials' acts).

129. See generally ROBINSON ET AL., supra note 128 , at 2-10 (contrasting the growth of administrative agencies in the late 19th century with the small size of the federal government at the founding).

130. See Developments in the Law-Federal Habeas Corpus, supra note 56, at 1238 (observing that historically, "[w]hile habeas review of a court judgment was limited to the issue of the sentencing court's jurisdictional competency, an attack on an executive order could raise all issues relating to the legality of the detention").

131. At common law, superior courts consisted of the House of Lords, the Chancery, the King's Bench, the Common Pleas, the Exchequer, the Palatine courts, and the Courts of Assize. See 4 STRoud's JUdiclal DictionaRY 2559 (John S. James ed., 5th ed. 1986). Inferior courts included local courts of quasi-criminal jurisdiction, such as the London Lord Mayor's Court and the ancient Borough Court of Record. See id. at 1289-90. Inferior courts also included courts of "special jurisdiction" whose jurisdiction was limited to particular areas or to redress particular injuries, such as the Commissioners of the Sewcrs. See 3 BLACKSTONE, supra note 94, at *71-85; see also 9 HALSBURY's LAWS OF ENGLAND, supra note 111 , at 349-50, 576-81 (discussing various courts considered inferior by virtue of their specialized jurisdiction). 
or by legal custom. ${ }^{132}$ In addition, superior courts were subject only to the control of other courts through appeal, whereas inferior courts were subject to control through the various prerogative writs, such as habeas corpus. ${ }^{133}$

Unlike judgments of superior courts, which were largely immune from habeas review, ${ }^{134}$ judgments of inferior courts were subject to searching review on habeas. In part, this stemmed from the requirement that inferior courts demonstrate jurisdiction with great detail and specificity. ${ }^{135}$ Because a superior court did not have to enumerate or specify the causes on which an imprisonment was based, it provided less opportunity to find fault with the "cause expressed." 136 In contrast, inferior courts had to establish the "full circumstances and grounds upon which an imprisonment is ordered . . in both the warrant and the return." 137 Therefore, superior courts could not only ensure that inferior courts acted within their jurisdiction, but they could also exercise review over nonjurisdictional claims, ${ }^{138}$ including errors of law ${ }^{139}$ and, at times, factual findings. ${ }^{140}$ In fact, great reliance was placed on superior courts, such as the King's Bench, to review the decisions of inferior courts. ${ }^{141}$ As with their review of executive detention, superior courts' strict

132. See 4 StRoud's Judicial Dictionary, supro note 131. at 2559.

133. Inferior courts could, for example, be compelled to exercise their jurisdiction by mandamus or could be restrained from doing so by prohibition, and their decisions could be quashed by certionan. See 1 JowITT's DICTIONARY OF ENGLISH LAW 493 (John Burke od.. 2d ed. 1977).

134. See AMNON RUBENSTEIN, JURISDICTION AND ILEGALTY 110 (1965); see also W. FORSTTH, CASES AND OPINIONS ON CONSTTtUTIONAL LAW 451 (London. Sievens \& Haynes 1869) (contrasting the scope of review between "commitments by regular Courts of competent jurisdiction and commitments under a special authority given by Act of Parliament"); cf. BAKER. supra note 84. at 117 (observing that judgments by the common law courts "could fairly be treated as final and conclusive" in part because those judgments reflected "[t]he kind of attention now given on appeal").

135. See Peacock v. Bell, 85 Eng. Rep. 84. $87-88$ (K.B. 1667) ("IN]othing shall be intended to be out of the jurisdiction of a Superior Court, but that which specially appears to be so: and, on the contrary. nothing shall be intended to be within the jurisdiction of an Inferior Coun but that whuch is so expressly alleged.").

136. Codd v. Turback, 81 Eng. Rep. 94, 94 (K.B. 1615), quoted in RUBENisteis, supra note 134, at 109 n.2; see also SHARPE, supra note 86, at $47-48$ (observing that. "as a practical matter. the cours never allowed habeas corpus to be used as a means of reviewing the decisions of supenor cours").

137. RUBENSTEIN, supra note 134, at 111 .

138. See Woolhandler, supra note 116, at 589 (observing that superior coun neview of infenor courts approached a "full review on the merits"); see also Ex pane Watkins, 28 U.S. (3 Pet.) 193. 205 (1830) (Marshall, C.J.) (distinguishing review of superior and inferior court judgments); Oaks, supra note 71. at 456-57 (noting that the scope of review of inferior court judgments has always been broader than judgments of superior courts).

139. See, e.g., R. v. White, 20 Howell's State Trials 1376, 1377 (K.B. 1746) (construng a statutory exemption in an impressment case); R. v. Nathan, 93 Eng. Rep. 914 (K.B. 1730) (per cunam) (construing a statute in reviewing a commitment by bankruptcy commissioners); Gardener's Case. 78 Eng. Rep. 1048 (K.B. 1600) (reviewing a claim of statutory construction following a summary conviction by a jusuce of the peace).

140. See, e.g., Good's Case, 96 Eng. Rep. 137 (K.B. 1760) (reviewing an impressed saulor's affidavit stating that he was a ship-carpenter and thus exempt from impressment); see also BAKER. supra note 84. at 108 (observing that the common law courts closely supervised the Coun of Admiralty's judgments).

141. Blackstone described the jurisdiction of the King's Bench as "high and transecendenl[.].... keep[ing] all inferior jurisdictions within the bounds of their authonty." 3 BLACNSTONE, supra note 94. at *42. 
control of inferior courts through habeas corpus underscores the writ's structural role and the reasons underpinning a broad scope of review.

An additional, overlapping distinction was made between courts of record and other courts. Courts of record were defined by their ability to fine and imprison for contempt, as well as by the fact that their acts were recorded on parchment for perpetual memory and testimony. ${ }^{142}$ While the superior common law courts of Westminster were the primary courts of record, numerous inferior courts, such as justices of the peace, ${ }^{143}$ were also courts of record. ${ }^{144}$ In contrast, rival jurisdictions of the common law courts, such as the Admiralty ${ }^{145}$ and the Court of Requests, ${ }^{146}$ were not courts of record. In general, courts of record were subject to narrower review on habeas. ${ }^{147}$ Courts of record that were also inferior courts, however, such as the Sewers Commission, were still subject to considerable scrutiny. ${ }^{148}$ Indeed, this suggests that it was precisely these courts' ability to fine and imprison that posed a greater threat to the liberty of the subject, thereby implicating the need for more searching review on habeas corpus.

\section{Absence of Trial by Jury}

Another, related factor prompting a broad scope of review on habeas was the absence of a trial by jury. For those facing criminal charges, trial by jury was historically viewed as the preeminent safeguard of liberty in England. ${ }^{149}$

142. See 9 HALSBURY's LAWS OF ENGLAND, supra note 111, at 346-48; 1 JowITT's DictionARY OF ENGLISH LAW, supra note 133, at 493; see also United States v. Barnett, 376 U.S. 681, 699-700 (1964) (emphasizing that the power to fine and imprison for contempt has historically been an inherent power of all courts of record); 2 THE LAW DiCTIONARY Courts (T.E. Tomlins ed., London, Andrew Strahan 1797) (unpaginated dictionary) (stating that courts of record had the power to hold plea, according to the course of the common law, in real, personal, and mixed actions, where the debt or damage amounted to 40 shillings or more). Superior courts were always courts of record. See Woolhandler, supra note 116, at 589 n.85.

143. See Pemell v. Southall Realty, 416 U.S. 363, 381 (1974) ("[Justices of the peace] were judges of record and their courts, courts of record."). But see Capital Traction Co. v. Hof, 174 U.S. 1, 17 (1899) (denying that, at least in the United States, justices of the peace have ever been considered courts of record); see also Margreth Barrett, The Constitutional Right to Jury Trial: A Historical Exception for Small Monetary Claims, 39 HASTINGs L.J. 125, 157 n.155 (1987) (noting that the distinction between a court of record and a court not of record has never been precise).

144. See 1 JOWITT'S DICTIONARY OF ENGLISH LAW, supra note 133, at 493.

145. See 1 W.S. HOLDSWORTH, A HISTORY OF ENGLISH LAW 316 (1908) (observing that in the 17 th century the common law courts denied Admiralty its status as a court of record, a status which was restored by statute during the 19 th century).

146. See Barrett, supra note 143 , at 157 n.155.

147. See SHARPE, supra note 86 , at 48 (discussing the "sanctity" of superior court judgments).

148. For example, the jurisdiction of the Sewers Commission, a court of record, was construed narrowly and held to the "discretionary coercion of his majesty's court of kings bench." 3 BLACKSTONB, supra note 94, at *74; see also infra notes 184-193 and accompanying text (discussing other inferior courts of record).

149. See BAKER, supra note 84, at 416 ("Trial by jury became the palladium of English liberty."); 3 BLACKSTONE, supra note 94, at *379 (calling trial by jury "the glory of the English law"). Trial by jury was subsequently incorporated into the U.S. Constitution. See U.S. CONST. art. III, $\S 2$, cl. 3 ("The Trial of all Crimes, except in Cases of Impeachment, shall be by Jury . . . "); id. amend. VI ("In all criminal 
Toward the end of the sixteenth century, as habeas corpus emerged as a means of protecting individual liberty, it became associated with the right to trial by jury. ${ }^{150}$ The existence of jury trial as the underlying safeguard affected the function of habeas review. Thus, in criminal matters, where the petitioner had a jury trial, habeas tended to play the important but limited function of compelling adherence to pretrial procedure and the right to a speedy jury trial. ${ }^{151}$ Indeed, the rule against controverting the truth of the facts stated in a return to a writ of habeas corpus was predicated on the historic role of juries as factfinders, whose verdicts judges resisted preempting on habeas. ${ }^{152}$

In the area of noncriminal commitments and summary criminal convictions, however, the defendant lacked the safeguard of jury trial, and habeas played a different role. In reviewing nonjury proceedings such as bankruptcy, ${ }^{153}$ impressment, ${ }^{154}$ and summary criminal convictions by justices of the peace, ${ }^{155}$ courts exercised a broader scope of review.

\section{No Other Available Remedy}

Lastly, a petitioner's lack of any other remedy prompted a broad scope of review on habeas. Thus, courts refused to be bound by the four corners of a return in impressment cases, where sailors were forcibly taken abroad and out

prosecutions, the accused shall enjoy the right to a speedy and public trial, by an impartial jury of the State and district wherein the crime shall have been committed . . . ."); see also THE FEDERALIST No. 83, at 499 (Alexander Hamilton) (Clinton Rossiter ed., 1961) ("The friends and adversaries of the plan of the convention, if they agree in nothing else, concur at least in the value they set upon the trial by jury ... ."). The Supreme Court has consistently emphasized the fundamental value of trial by jury. See, e.g., McCleskey v. Kemp, 481 U.S. 279, 309 (1987) (discussing the Court's "recognition that the inestimable privilege of trial by jury . . . is a vital principle, underlying the whole administration of criminal justice" (citation omitted)); see also id. (calling the jury the criminal defendant's "fundamental" safeguard against racial prejudice).

150. See R. v. Whistler, 90 Eng. Rep. 1018, 1018 (K.B. 1702) (Holt, C.J., dissenting) (explaining the danger of summary convictions by justices of the peace without the safeguard of tnal by jury guaranteed by the Magna Carta); E. INGERSOLL, THE HISTORY AND LAW OF THE WRT OF HABEAS CORPUS 1-2 (Philadelphia, T.K. \& P.G. Collins 1849) (discussing the link between habeas corpus and the Magna Carta's guarantee that no man ought to be imprisoned "against the law of the land"); see also THE FEDERALIST No. 83, at 499 (Alexander Hamilton) (discussing the link in protecting liberny between habeas corpus and trial by jury in criminal cases).

151. See 9 HoLDSWORTH, supra note 84, at 118.

152. See infra text accompanying notes 204-206.

153. See, e.g., R. v. Nathan, 93 Eng. Rep. 914,914 (K.B. 1730) ("It is very dangerous to let people depart from the words of the [Bankruptcy] Act, where these spectal authoritles are given."); see also Crowley's Case, 36 Eng. Rep. 514, 538 (Ch. 1818) (refusing to be bound by the finding of the banknupicy commissioners). Though Crowley's Case was decided after the 1816 Act. 56 Geo. 3. ch. 100. \$3. which allowed the truth of the facts in a retum to be controverted, the court did not refer to the Act in discussing the scope of review on habeas.

154. See, e.g., Goldswain's Case, 96 Eng. Rep. 711.712 (C.P. 1778) ("I do not concelve, thal cuther the Court or the party are concluded by the retum of a habeas corpus, but may plead to it any special matter necessary to regain his liberty.").

155. See, e.g., Gardener's Case, 78 Eng. Rep. 1048 (K.B. 1600) (reviewing a claum of statutory construction on habeas corpus); BAKER, supra note 84 , at 419 (observing that the expanded powers of summary conviction "infringed the principle that a man should only be judged by hus peers, and ... were regarded with deep suspicion by the superior judges" (emphasis added)). 
of the reach of the King's courts. ${ }^{156}$ The threat to liberty did not have to be so drastic as removal from the Kingdom, however. Commitments for contempt-even by superior courts-prompted a broad scope of review on habeas ${ }^{157}$ because, absent such review, a prisoner's only recourse was to seek release from the same court that had committed him. Thus, habeas corpus, called by Blackstone "the most celebrated writ in the English Law,"158 involved broader judicial review where it presented the last resort for an individual facing a loss of liberty.

\section{Scope of Habeas Review in Noncriminal Matters and Summary Criminal Convictions}

This section demonstrates that the potentially broad scope of habeas review in noncriminal matters, as well as summary criminal convictions, encompassed questions of law, abuses of discretion, and, in some instances, factual findings.

\section{Questions of Law}

At least in noncriminal cases and summary convictions by inferior courts, questions of law were reviewable through the common law writ of habeas corpus. This is demonstrated by the comments of the various leading judges on a bill proposed in 1758, the practice of "confessing and avoiding" the return, and the review of legal claims by superior courts in various contexts.

In 1758 , the House of Lords rejected a bill that would have both extended the procedural protections of the Habeas Corpus Act of 1679 to noncriminal cases and allowed prisoners to controvert the truth of the facts stated in returns in noncriminal cases. ${ }^{159}$ It was well established, however, that questions of law were reviewable on habeas. During debate on the 1758 bill, the House of

156. See Goldswain's Case, 96 Eng. Rep. at 712 (declaring that the court "could not willfully shut [its] eyes" to the highly sympathetic facts appearing in the sailor's affidavit though absent from the return); see also Sommersett's Case, 20 Howell's State Trials I, addendum at 1378, 1380 (K.B. 1772) (reprinting a letter from Sir Michael Foster to Justice Baron Parker, dated May 24, 1758, in which Foster calls the alternative remedy, an action for a false retum, "a rope thrown out to a drowning man, which cannot reach him, or will not bear his weight"). Notably, it was an impressment case that sparked the proposal of the 1758 bill and thus, indirectly, the judges' discussion about the writ's scope. See INGERSOLL, supra note 150 , at 9; SHARPE, supra note 86 , at 68.

157. See, e.g., Bushell's Case, 124 Eng. Rep. 1006, 1007 (C.P. 1670) (stating that the court's "judgment ought to be grounded upon [its] own inferences and understandings" and not upon those of the court that had committed the juror for contempt); see also Hodges v. Humkin, 80 Eng. Rep. 1015, 1016 (K.B. 1613) (releasing a prisoner committed by the mayor of his town for contempt for his use of "undecent speeches"). Commitments for contempt by the houses of Parliament, however, may have represented an exception to this rule. See, e.g., Earl of Shaftsbury's Case, 86 Eng. Rep. 792, 799-800 (K.B. 1677) (holding that while the return would have been "ill and uncertain" if made by "an ordinary Court of Justice," judgments of Parliament were not justiciable).

158. 3 BLACKSTONE, supra note 94 , at $* 129$.

159. For the full text of the bill, see 15 PARLIAMENTARY HISTORY $871-74$ (London, T.C. Hansard 1813). 
Lords ordered the judges of the common law courts to provide their opinions on the proposed law. ${ }^{160}$ Even those judges who denied that the truth of facts in the return could be controverted conceded that habeas review extended to questions of law. ${ }^{161}$ The opinion of Chief Justice Wilmot leaves no doubt on this issue. Even if, as Wilmot contended, a cour was precluded on habeas from inquiring into whether the cause of confinement was "true or . . false," it nonetheless could establish whether the cause was a "good or bad reason."162 The writ, Wilmot thus claimed, was not "framed or adapted to litigating facts," but provided "a summary short way of taking the opinion of the Court upon a matter of law." 163

Moreover, judges were not confined to the four corners of a return in determining whether it was sufficient in point of law to justify a given detention. By "confessing and avoiding" a return to a writ of habeas corpus, a prisoner could introduce facts that did not contradict those in the return but that provided an alternative justification for them. ${ }^{164}$ This practice, which has been compared to the use of special verdicts, ${ }^{165}$ enabled courts to review questions of law on habeas. ${ }^{166}$ In Gardener's Case, ${ }^{167}$ for example, a prisoner, summarily convicted by a justice of the peace ${ }^{163}$ for carrying a "hand-gun," confessed and avoided the return to habeas corpus to gain review over a straight question of law: Was a "dagg" a "hand-gun" as defined by the controlling statute? ${ }^{169}$ The court ruled against the prisoner on that issue, ${ }^{170}$ but discharged him on the grounds that, as a sheriff, he was exempt from the act's prohibition against carrying such guns. Similarly, in Swallow v. City of London, ${ }^{171}$ a prisoner, committed for refusing to accept the office of

160. See, e.g., Sir John Eardley Wilmot, Opinion on the Writ of Habeas Corpus, 97 Eng. Rep. 29, 29. 30 (1758).

161. See CHURCH, supra note 51, at $228 \mathrm{n} .1$ (noting the views of Jusuces Baron Parker. Baron Smyth. Baron Adams, Wilmot, and Dennison).

162. Wilmot, supra note 160 , at 43 .

163. Id. (emphasis added).

164. See 2 HAwKINS, supra note 51. at 113 ("[A] Man may confess and arold such a Relum, by admitting the Truth of the Matters contained in it, and suggesting others not repugnant, which take off the effect of them.").

165. See, e.g., King v. Hawkins, 92 Eng. Rep. 849.849 (K.B. 1715) (Panker. CJ.) ("IAs] to the truth of facts, the return of the officer is the same as a special verdict ...." (emphasis added)). In Hawkins, the prisoner was convicted for "backbearing and carrying away a deer out of the forest." Id. While the court refused to review the question of whether the prisoner had obtained the deer owner's consent, it nonetheless reviewed the legal issue of what constituted a "taking" in this context. Id.

166. The practice might today be compared to a motion for summary judgment, by which a coun may decide a case in which there is no dispute between the parties over any materal fact. See FED. R. CIV. P 56.

167. 78 Eng. Rep. 1048 (K.B. 1600).

168. For further description of justices of the peace, see infra notes 184-188 and accompanyıng text.

169. Gardener's Case, 78 Eng. Rep. at 1048; see also SHARPE, supra note 86. al 67 (ciung Gardener's Case as an example of confessing and avoiding a retum). "Dagg" has been defined as a "kind of heavy pistol or hand-gun." 4 OXFORD ENGLISH DICTIONARY 213 (2d ed. 1989).

170. See Gardener's Case, 78 Eng. Rep. at 1048 (holding that a "dagg" was a "hand-gun within the statute, although ... not named therein").

171. 82 Eng. Rep. 1110 (K.B. 1666); see also ROLLIN C. HURD. A TREATSE ON THE RIGHT OF 
alderman to which he had been elected, successfully confessed and avoided the return by demonstrating that as an officer of the King's mint he was legally exempt from all city offices. ${ }^{172}$

In numerous noncriminal contexts, review on habeas was not limited strictly to whether the committing court had acted within its jurisdiction, but encompassed whether its decision conformed to the governing statute. ${ }^{173}$ In reviewing the commitments of contempt by bankruptcy commissioners, for example, common law courts adjudicated claims of statutory construction regarding the meaning, nature, and scope of interrogatories used by the commission. ${ }^{174}$ In discharging one prisoner for the commission's misconstruction of the statute granting it power to issue interrogatories, Chief Justice Holt emphasized the principle underpinning judicial review on habeas: "It is very dangerous to let people depart from the words of the Act, where these special authorities are given."175 Similarly, in cases involving malpractice, ${ }^{176}$ husbands and wives, ${ }^{177}$ and local trade ordinances, ${ }^{178}$ courts reviewed nonjurisdictional claims of statutory construction.

Cases involving the impressment of seamen powerfully demonstrate the reviewability of legal error on habeas. Over the course of four wars fought against France during the late seventeenth and eighteenth centuries, ${ }^{179}$ Parliament enacted a complex statutory scheme regulating the Admiralty's power

PERSONAL LIBERTY, AND ON THE WRT OF HABEAS CORPUS 265 (Albany, W.C. Little \& Co. 2d ed. 1876) (providing an excerpt in English of Swallow, which was written in Law French). Hawkins cites Swallow as an example of confessing and avoiding the return. See 2 HAWKins, supra note 51, at 113.

172. For another example of confessing and avoiding the retum to obtain review on a question of law, see Ex parte Eggington, 118 Eng. Rep. 936, 941 (Q.B. 1853), which held that there could be no arrest on a privileged day.

173. See SHARPE, supra note 86 , at 39 ("What would suffice as a sufficient retum was not defined with precision. Enough had to appear to satisfy the court that the imprisonment was a legal one, and the court did not have to be stymied by technical rules." (emphasis added)).

174. See, e.g., R. v. Nathan, 93 Eng. Rep. 914 (K.B. 1730) (per curiam) (construing a statute to require that interrogatories be exhibited and a deponent be given time to answer); Hollingshead's Case, 91 Eng. Rep. 307 (K.B. 1702) (discharging a prisoner when the bankruptcy commission failed to adhere to the statute); Bracy's Case, 90 Eng. Rep. 547 (K.B. 1701) (holding that the commission's use of the word "embezil" in an interrogatory was not within the meaning and intent of the bankruptcy statute). Indeed, the bankruptcy cases support the notion, suggested in Bushell's Case, 124 Eng. Rep. 1006, 1007 (1670), that commitment for contempt generally led to broad review on habeas. See supra note 157 and accompanying text.

175. Nathan, 93 Eng. Rep. at 914.

176. See, e.g., Dr. Groenvelt's Case, 91 Eng. Rep. 1038 (K.B. 1702) (holding, as a matter of law, that the statute granting the power to fine to the College of Physicians did not divest the King of his power to pardon a fine in the course of pardoning the offense itself); see also Dr. Alphonso's Case, 80 Eng. Rep. 1105 (K.B. 1614) (holding a retum insufficient for failure to demonstrate the cause of commitment).

177. See, e.g., Lister's Case, 88 Eng. Rep. 17 (K.B. 1721) (citing the prior execution of a separation deed); see also The Queen v. Jackson, I Q.B. 671, 677-78 (1891) (reviewing cases).

178. See, e.g., Hutchins v. Player, 124 Eng. Rep. 585, 585-86, 592 (C.P. 1663) (reviewing the validity of a municipal ordinance, based on a local custom, which regulated the sale of cloth).

179. See generally GERALD J. GOODWIN ET AL., A HISTORY OF THE UNITED STATES TO 1877, at 92 (2d ed. 1985) (listing the wars England fought against France during this period). 
to impress seamen into military service for the Crown. ${ }^{180}$ In numerous instances, habeas enabled common law courts to review petitioners' claims that they were exempt from impressment under a particular act ${ }^{181}$ or that a statute granting an exemption was still in force. ${ }^{182}$ Although the common law courts supported the power to impress as an executive prerogative, they "strictly limited [its exercise] within the bounds prescribed to it by custom or by statute."183

Likewise, cases reviewing decisions of justices of the peace ${ }^{184}$ demonstrate that questions of law were reviewable on habeas. The justices of the peace were given broad power over various criminal matters ${ }^{185}$ as well as over the enforcement of an array of economic legislation, making them key players in the administrative operation of the state in medieval and early modern England. ${ }^{186}$ The breadth of the power of justices of the peace, however, and their status as inferior courts, made the superior common law courts eager to supervise their activities through habeas corpus, as well as through the writ of certiorari ${ }^{187}$ and mechanisms of informal control. ${ }^{188}$

There are numerous instances of the use of habeas corpus to review orders of the justices of the peace ${ }^{189}$ as well as those of other quasi-administrative officials. A notable example is the review of decisions by the Sewers Commission, the membership of which traditionally overlapped with that of the justices of the peace, ${ }^{190}$ and which had broad power to order surveys and

180. See I RIChaRd GUdE, THE PRACTICE OF THE CROWN SIDE OF THE COURT OF KING'S BENCH 281-88 (London, R. Pheney et al. 1828) (citing statutes and cases).

181. See, e.g., R. v. White, 20 Howell's State Trials 1376, 1377 (K.B. 1746) (discharging a seaman after determining that he was statutorily exempt from impressment and stressing that he had "no other remedy").

182. See, e.g., Ex parte Drydon, 101 Eng. Rep. 235 (K.B. 1793) (Kenyon, C.J.) (relying on provisions in several other acts to determine that the statute providing an exemption remained in force, and therefore discharging the sailor).

183. DICEY, supra note 126, at 223-24; see also Deybel's Case, 106 Eng. Rep. 926,928 (C.P. 1821) (discharging a seaman because in impressment cases it "ought . . to appear, on the face of the retum, that the case is brought accurately within the provisions of Act of the Parliamen" (cmphasis added)). Though decided after 1816, Deybel's Case makes no reference to the $1816 \mathrm{Act}$ in discussing the scope of review on habeas.

184. Justices of the peace were generally laymen from the local gentry appointed by the Crown. See 1 HOLDSWORTH, supra note 145, at 126.

185. See JoHN P. DAWSON, A History OF LAY JUDGes 136-42 (1960).

186. See id. at 139-40 (describing the jurisdiction of a justuce of the peace over the system of labor compensation and wage regulation that followed the Black Death of 1348, the manienance of roads and waterways, and the regulation of trade).

187. See Woolhandler, supra note 116, at 589 n.86 (discussing the frequency with which common law courts reviewed decisions by justices of the peace and sewers commissioners).

188. Informal control over justices of the peace was exercised through advice given by the justices of the assize. Again, the goal was to ensure not merely that justuces of the peace acted within their jurisdiction, but also that they interpreted the law correctly. The usual procedure was to adjourn difficult cases until the next assize and to consult with the judge who would "statel] the rules of law applicable." EDITH G. HeNDERSON, Foundations OF ENGLiSh Administrative Lai' 26 (1963) (emphasis added) Informal control was also exercised through the issuance of general "resolutions" by royal judges stating the law in matters conceming justices of the peace. See id. at $27-28$ (discussing a resolutuon concerning inns).

189. See id. at 95 (citing cases).

190. See id. at 28. 
repairs of local infrastructure. ${ }^{191}$ In Hetley v. Boyer, ${ }^{192}$ the King's Bench discharged on a writ of habeas corpus an individual imprisoned for refusing to release a suit against the Sewers Commission challenging the taxation system it used to finance projects. In invalidating the Commission's taxation system, the King's Bench illustrated that habeas protected the liberty of the subject by ensuring that administrative agencies acted in conformance with existing law. ${ }^{193}$

\section{Abuses of Discretion}

The concept of "discretion" was not well developed at common law. The idea that an agency or individual had to act within its delegated authority, however, suggests that abuses of that discretion, like the interpretation of statutes, were reviewable on habeas. In invalidating the taxation scheme established by the sewers commissioners in Hetley v. Boyer, the King's Bench stated that although the statute granted the commissioners discretion in the exercise of their functions, such discretion had to be exercised wisely and according to established legal principles. ${ }^{194}$ Likewise, the courts concluded with respect to impressment that habeas provided review of the Admiralty's alleged abuses of discretion on the ground that the Admiralty's considerable power over such matters should not "be pushed te the extreme."195 Similarly, in cases determining whether a husband's custody of his wife was unlawful, the issue often turned on whether a husband abused the discretionary power he had over his wife ${ }^{196}$ given her subordinate status as a feme covert. ${ }^{197}$

191. See id. The Commission has been described as a "full-scale 'administrative organ." Louis L. Jaffe \& Edith G. Henderson, Judicial Review and the Rule of Law: Historical Origins, 72 LAW Q. REv. 345,349 (1956). See generally HENDERSON, supra note 188, at 28-32 (discussing the origins and development of the Sewers Commission).

192. 79 Eng. Rep. 287 (K.B. 1613).

193. See HENDERSON, supra note 188 , at 7 (noting that such quasi-administrative law cases illustrate the principle that, in the 17th century, "every question of statutory construction was jurisdictional"). Although judicial review of Sewers Commission decisions declined after Hetley v. Boyer because of strong opposition by the Privy Council, it resurfaced again a few decades later. See id. at 100. Subsequent review of decisions by the Sewers Commission, and by justices of the peace generally, was increasingly accomplished by writ of certiorari, rather than by habeas corpus. See id. at 95 . The general shift to certiorari in the administrative context, however, was not due to the unavailability of habeas, but rather to the fact that certiorari did not require that the petitioner go first to jail for contempt. See id. at 94-95. One might draw an analogy to the decline in the use of habeas corpus to review final orders of deportation after the passage of the Immigration and Nationality Act of 1961, Pub. L. No. 87-301, $\S 106$ (a), 75 Stat. 650, 651 (codified at 8 U.S.C. \& 1105 a (1994) (repealed 1996)), which enabled aliens to challenge deportation orders directly through a petition for review. See supra note 16.

194. See Hetley, 79 Eng. Rep. at 287.

195. Ex parte Boggin, 104 Eng. Rep. 484,484 n.(a) ${ }^{2}$ (K.B. 1811).

196. See, e.g., King v. Lee, 83 Eng. Rep. 482 (K.B. 1676); see also BAKER, supra note 84, at 92 (discussing the use of habeas by Chief Justice Coke to override the chancellor's discretionary exercise of his contempt power).

197. See 1 BLACKSTONE, supra note 94 , at $* 430$ (describing how "the very being or legal existence of the woman is suspended during the marriage, or at least is incorporated and consolidated into that of the husband: under whose wing, protection, and cover, she performs every thing"). 


\section{Factual Findings}

Notwithstanding the rule against controverting the truth of the return, judges were not entirely precluded from reviewing facts on habeas corpus. ${ }^{193}$ Five of the nine judges questioned by the House of Lords on the proposed 1758 bill that would have provided for review of facts in noncriminal cases categorically denied that they were bound by the facts set forth in the return, ${ }^{199}$ as did a sixth judge who was absent. ${ }^{200}$ Lord Mansfield strongly opposed the bill because he believed the law already permitted what the bill was trying to accomplish. ${ }^{201}$ Moreover, even Chief Justice Wilmot and the remaining judges who supported the rule against controverting the truth of facts provided in the return ${ }^{202}$ conceded that, in practical terms, questions of fact could be entertained on habeas. ${ }^{203}$

The main constraint on judicial review of the facts in a return to habeas corpus was the principle that juries must answer to questions of fact and judges to questions of law. ${ }^{204}$ Judges who refused to review facts emphasized the venerable common law rule that habeas corpus would not supplant trial by jury for the ultimate determination of guilt or innocence in criminal cases. ${ }^{205}$ In criminal matters, therefore, such review was generally limited to questions of pretrial detention. ${ }^{206}$ In noncriminal matters, however, judges had greater

198. See HURD, supra note 171 , at 259 (stating that, at least in noncriminal matters, the "rule" agaınst controverting the truth of facts in the return was "not, in its absolute form, the law").

199. See id. at 259 (describing opinions of Lord Chief Jusuce Willes and Jusuces Nocl. Bathurst. Clive, and Baron Legge).

200. See id. (describing the opinion of Justice Foster).

201. See SHARPE, supra note 86 , at 66 n.16.

202. See Wilmot, supra note 160 , at 43 ("The Coun say's. 'Tell the reason why you confine him." The Court will determine whether it is a good or bad reason; but not whether it is a true or false one. The Judges are not competent to this inquiry; it is not their province, but the province of a jury. to determine it . . . .); see also INGERSOLL, supra note 150. at 12-13 (quoting Justice Baron Smythe's view that judges were bound by the "facts set forth in the return to the wnt of habeas corpus. [which) can be controverted or contradicted only by the verdict of a jun." (emphasis added)).

203. See Wilmot, supra note 160, at 66-67; see also HURD, supra note 171. at 261 (notung Wilmot's practice of indirectly allowing affidavits to contradict the facts stated in the return); of. 9 HOLDSWORTI, supra note 84, at 120 (observing that judges "mitigated [the] harshness" of the restnction agaunst controverting the truth of the return "by adopting the practsce of making a rule that a person holding another in his custody should show cause for his detention. and of discharging such person if no cause were shown").

204. See, e.g., 3 BLACKSTONE, supra note 94, at *60 ("If facts are disputed, they are sent down to be tried in the country by the neighbors; but the law, ansing upon those facts. is delermined by the judges above ...."); see also supra note 202.

205. See, e.g., Ex parre Beeching, 107 Eng. Rep. 1010 (K.B. 1825) (explanning the refusal of judges to try a party on affidavits in criminal cases): HURD. supra notc 171 . al $259-60$ (cilung judges' refusals to try the facts averred by affidavits). But see SHARPE, supra note 86, at 65 (arguing that it was because the writ did not raise factual issues that there was no jury. and that the absence of a jury did not preclude consideration of facts).

206. See, e.g., R. v. Greenwood, 93 Eng. Rep. 1086 (K.B. 1739) (acceptung affidavils of eight "credible persons" introduced in a case involving a defendant indicted for highway robbery. but refusing to release the defendant on bail); Barney's Case, 87 Eng. Rep. 683 (K.B. 1701) (allowing bail for a woman indicted for petty treason for killing her husband after allowing her to introduce affidavils of fact showing that it was a malicious prosecution). 
freedom to controvert the facts stated in the return. First, there was no concern with usurping the historic role of the jury. Second, commitment on criminal charges implied some previous judicial investigation. ${ }^{207}$ Third, noncriminal commitments by inferior courts had always required greater justification of jurisdiction than judgments of superior courts. ${ }^{208}$ It is not surprising, therefore, that while the right to controvert the truth of a return in noncriminal cases was not granted by statute until 1816 , the instances in which prisoners contradicted facts in the return were too numerous to specify. ${ }^{209}$

\section{THE COMMON LAW WRIT AND REVIEW OF DEPORTATION ORDERS}

Although there is no direct link between the writ's use at common law and the contemporary deportation context, there are sufficient similarities to make a persuasive analogy. ${ }^{210}$ All five factors governing the scope of review of the common law writ of habeas corpus are present in deportation cases today. This not only suggests that deportation orders would have been reviewable at common law, ${ }^{211}$ but also that the scope of review would have been broad, extending to questions of law, abuses of discretion, and factual findings. Thus, the proposition that the Constitution requires review only of deportation orders that would result in "a grave constitutional error,"212 or in "a fundamental miscarriage of justice," ${ }^{213}$ fails to recognize the applicability and scope of the common law writ of habeas corpus. Likewise, the suggestion that habeas review of deportation orders should be "limited to the enforcement of due

207. See HURD, supra note 171 , at 268.

208. See supra Subsection II.C.3.

209. See HURD, supra note 171 , at 271 . For instances of noncriminal confinement whero courts reviewed facts on habeas, see, for example, $R$. v. Turlington, 97 Eng. Rep. 741 (K.B. 1761), in which the court refused to remand a woman to the custody of a "private mad-house" on the basis of doctors" affidavits and the court's own examination of the woman; and King v. Lee, 83 Eng. Rep. 482, 482 (K.B. 1676), in which the court entertained a factual hearing before ruling on a husband's alleged "ill usage, imprisonment and danger of [his wife's] life." But see King v. Viner, 84 Eng. Rep. 829 (K.B. 1676) (stating in a case involving the Mayor of London's custody of another person's ward that the facts stated in a return to a writ of habeas corpus could not be traversed). In fact, in several impressment cases, the court made findings of fact to avoid reaching particularly difficult questions of law. See, e.g., Goldswain's Case, 96 Eng. Rep. 711, 712 (C.P. 1778) (reviewing the facts in the sailor's affidavit to avoid ruling on the legality of Admiralty's general press warrant); Good's Case, 96 Eng. Rep. 137 (K.B. 1760) (accepting the petitioner's affidavit stating that he was a ship-carpenter and thus entitled to a previously established exemption to avoid ruling on the legality of another exemption based on the petitioner's status as a freeholder).

210. See Cohen, supra note 72 , at $186 \mathrm{n} .133$ (discussing the traditional use of the writ to challenge "commitments by bodies not being courts of law yet having the power to commit," and referring to the writ's 20th-century use in the immigration context); $c f$. Jones v. Cunningham, 371 U.S. 236, 238 (1963) ("English courts have long recognized the writ as a proper remedy even though the restraint is something less than close physical confinement.").

211. Cf. Fay v. Noia, 372 U.S. 391,450 (Harlan, J., dissenting) (suggesting the traditional applicability of the writ to aliens facing exclusion in discussing the writ's common law history).

212. E.g., Powell v. Jennifer, 937 F. Supp. 1245, 1252 (E.D. Mich. 1996). Similarly, the government has contended that the Constitution requires review only of "substantial constitutional" claims. E.g., Ramallo v. Reno, 114 F.3d 1210, 1214 (D.C. Cir. 1997).

213. E.g., Mbiya v. INS, 930 F. Supp. 609, 612 (N.D. Ga. 1996). 
process requirements"'214 ignores the writ's long history of use in noncriminal cases to gain judicial review over a range of claims.

\section{A. The Presence of the Five Factors}

All five factors discussed above are present in the contemporary immigration context. First, deportation involves fundamental interests "basic to human liberty and happiness," 215 and thus implicates the writ's highest function at common law-the safeguarding of personal liberty.

Second, deportation involves executive detention. Immigration judges and the Bureau of Immigration Appeals (BIA) are not Article III courts, but rather agencies under the authority of the Attorney General. ${ }^{216}$ The important role of habeas corpus under this scheme is powerfully illustrated by the Attorney General's decision in In re Soriano. ${ }^{217}$ Without public notice or hearing, the Attorney General vacated an earlier BIA decision that had held that the AEDPA's elimination of section 212(c) relief ${ }^{218}$ did not apply retroactively if an alien's application for relief was pending at the time of the Act's passage. ${ }^{219}$ The Attorney General held that the provision applies retroactively to pending section 212 (c) applications. ${ }^{220}$ Construing the jurisdictional provisions of the AEDPA and the IIRIRA to bar review of decisions by the Attorney General such as in In re Soriano ${ }^{221}$ would set the alarming

214. Id. (quoting Heikkila v. Barber, 345 U.S. 229. 235 (1954)).

215. Wong Yang Sung v. McGrath, 339 U.S. 33, 50 (1950); see also Delgadillo v. Carmichael, 332 U.S. 388, 391 (1947) ("The stakes [of deportation] are indeed high and momentous for the alien who has acquired his residence here."); Bridges v. Wixon, 326 U.S. 135, 154 (1945) (cmphusizung that the "liberty of an individual is at stake"); $\mathrm{Ng}$ Fung Ho v. White, 259 U.S. 276, 284 (1922) (stressing that deportation may "result . . . in loss of both property and life; or of all that makes life worth living"): ALElNikOFF \& MARTIN, supra note 46, at 854 (comparing the unique and high personal stakes of immigration to other administrative adjudications).

216. See 8 U.S.C. $\S 1103$ (a) (1994) (providing that a "determination and ruling by the Atrorney General with respect to all questions of [immigration] law shall be controlling"). Until 1973, immigration judges were known as "special inquiry officers" and served as "trial attomeys" in deportalion and exclusion Cases. ALEINIKOFF \& MARTIN, supra note 46, at 109. In 1983, immigration judges were moved from the Immigration and Naturalization Service (INS) into a new unit, the Executive Office of Immigmation Review (EOIR), located in the Department of Justice and directly accountable to the Assistant Attomey General. See id. The BIA, a multi-member review body appointed by the Attomey General, has never been part of the INS; instead, it has always been directly accountable to the Attomey General. See id. at 112 . While immigration judges' and the BIA's adjudication in deportation and exclusion cases has grown more "judicial" over the years, immigration judges and the BIA have been altacked for thetr lack of independence. See, e.g., Developments in the Lau-Immigration Policy and the Rights of Aliens, 96 HaRV. L. REV. 1286, 1363-66 (1983) (stressing the "enforcement mentality" in the BIA and the implict control of the Attomey General).

217. No. 3289, Op. Att'y Gen. (Feb. 21, 1997).

218. See AEDPA, Pub. L. No. 104-132, $\$ 440$ (d). 110 Stat. 1214, 1277 (1996) (amending 8 U.S.C. $\S 1182(\mathrm{C})$ (1994) (repealed 1996)).

219. See In re Soriano, No. A39186067, 1996 WL 426888 (B.I.A. June 27, 1996).

220. See In re Soriano, No. 3289, Op. Att'y Gen.

221. Compare Mayers v. Reno, 977 F. Supp. 1457, 1462-63 (S.D. Fla. 1997) (holdung that the court had no jurisdiction to review the Attomey General's decision), with Mojica v. Reno, 970 F. Supp. 130, 182 (E.D.N.Y. 1997) (holding that the courn had jurisdiction and reversing the Attomey General's deciston on the merits). Other courts have held that they retained jurisdiction to review the Altomey General's decision. 
precedent of making it the exclusive province of the executive branch to say what the law is in a matter affecting personal liberty. ${ }^{222}$ The acts would thereby denude the common law writ of habeas corpus of its core function as a safeguard of personal liberty and a check on arbitrary executive power. ${ }^{223}$

Third, review of deportation orders is akin to the review of decisions of an inferior court at common law. At common law, inferior courts were subject to the strict control of superior courts, which exercised a broad scope of review on habeas. ${ }^{224}$ Under the common law definition, both immigration judges and the BIA qualify as inferior courts because their jurisdiction is specialized and limited. ${ }^{25}$ In certain respects, immigration tribunals are like the King's conciliar courts, the extensive power of which the common law courts sought to supervise through habeas corpus. ${ }^{226}$ Indeed, immigration proceedings are arguably not even judicial in nature. ${ }^{27}$ Moreover, as Blackstone suggests, ${ }^{228}$ it was precisely those inferior courts able to impose significant sanctions $^{229}$ that implicated the functional role of habeas and subjected their decisions to the supervision of superior courts-a function today served in the immigration context by Article III courts.

Fourth, deportation is noncriminal ${ }^{230}$ and does not require trial by jury

but have upheld the decision on the merits. See, e.g., Gutierrez-Martinez v. Reno, No. Civ.A.1:97CV3361TWT, 1998 WL 7459, at *3-5 (N.D. Ga. Jan. 8, 1998).

222. Cf. INS v. Chadha, 462 U.S. 919, 951 (1983) ("The hydraulic pressure inherent within each of the separate Branches to exceed the outer limits of its power, even to accomplish desirable objectives, must be resisted."); Richard H. Fallon, Jr., Of Legislative Courts, Administrative Agencies, and Article III, 101 HARV. L. REV. 915, 970 (1988) (contending that the "rule of law requires that administrative deterninations of legal rights [of aliens] be open to review and thus to correction by the courts").

223. See supra Subsection II.C.2; see also THE FEDERALIST No. 83, at 499 (Alexander Hamilton) (describing the role of habeas corpus in protecting against "arbitrary methods of prosecuting pretended offenses," and "arbitrary punishments upon arbitrary convictions" (emphases added)); $c f$. Larry W. Yacklc, Explaining Habeas Corpus, 60 N.Y.U. L. REV. 991, 997 (1985) ("Properly conceived, the writ is not a procedural vehicle for the protection of physical liberty... but an instrument of govemmental administration employed to distribute authority and responsibility between courts of concurrent jurisdiction.").

224. See supra Subsection II.C.3.

225. See Kempe's Lessee v. Kennedy, 9 U.S. (5 Cranch) 173, 184, 185 n.1 (1809) (Marshall, C.J.) (defining inferior courts). Importantly, in Ex parte Watkins, 28 U.S. (3 Pet.) 193 (1830), Chiof Justice Marshall pointed out that lower federal courts were superior courts even though the Constitution and statutes limited their jurisdiction. Unlike federal courts, however, administrative agencies do not decide a wide range of issues, a factor recognized at common law as an attribute of inferior courts. See Woolhandler, supra note 116, at $589 \mathrm{n.86}$ (noting that inferior courts had "stinted, limiting jurisdiction" at common law). Moreover, in contrast to federal courts, administrative agencies generally do not have jurisdiction to decide the constitutionality of congressional enactments. See Johnson v. Robison, 415 U.S. 361,368 (1974).

226. See supra text accompanying notes $92-101$.

227. See Nakaranurack v. United States, 68 F.3d 290, 294 (9th Cir. 1995) (stating that "neither a ruling by an [immigration judge] nor a decision of the BIA constitutes a 'judicial proceeding ..."' (emphasis added)).

228. See supra note 148 (noting, for example, review of decisions by the Sewers Commission).

229. Immigration judges were recently given the power to hold parties in contempt. See 8 U.S.C.A. $\S 1229 \mathrm{a}$ (b)(1) (West Supp. 1997). And while deportation is noncriminal, the Court has described its consequences as particularly severe. See cases cited supra note 215 .

230. See INS v. Lopez-Mendoza, 468 U.S. 1032, 1038 (1984) (stating that a "deportation proceeding is a purely civil action to determine eligibility to remain in this country, not to punish an unlawful entry"); Harisiades v. Shaughnessy, 342 U.S. 580, 594 (1952) ("Deportation, however severe its consequences, has 
or other rights required by the Constitution in criminal proceedings. ${ }^{211}$ At common law, the absence of the safeguard of trial by jury triggered a broad scope of review on habeas. ${ }^{232}$

And fifth, because those facing deportation have no other remedy, ${ }^{233}$ the common law writ further supports a broad scope of review. ${ }^{234}$

\section{B. The Implications of a Broad Scope of Habeas Review}

The 1996 acts offer a glimpse of what a broad scope of habeas review would entail in the deportation context. Among other important issues, ${ }^{235}$ the following legal claim has been raised in challenges to the AEDPA and the IIRIRA: whether the acts' elimination of waivers of deportation pursuant to INA section 212(c) for aliens convicted of certain criminal offenses applies retroactively, regardless of how long ago the crime was committed. ${ }^{236}$ The issue presents a straight question of law with dramatic implications for individual personal liberty, ${ }^{237}$ the resolution of which requires independent judicial review. ${ }^{238}$ Indeed, the importance of such review is underscored by the fact that several courts have refused to follow the Attorney General's decision in In re Soriano, holding that the acts' elimination of section 212(c) relief does not apply retroactively. ${ }^{239}$ Putting the merits aside, however, the

been consistently classified as a civil rather than a criminal procedure.").

231. See, e.g., Galvan v. Press, 347 U.S. 522 (1954) (holding that the Ex Post Faclo Clause does not apply to deportation); Argiz v. INS, 704 F.2d 384, 387 (7th Cir. 1983) (per curnam) (holdıng that the Speedy Trial Clause does not apply to deporation).

232. See supra Subsection II.C.4.

233. See Stone v. INS, 514 U.S. 386, 399 (1995) (statung that the "consequences of deponation are ... final, unlike orders in some other administratuc contexts"). Wbodby v INS, 385 U S 276, 285 (1966) ("This Court has not closed its eyes to the drastic deprwations that may follow when a resident of this country is compelled by our Govemment to forsake all the bonds formed here and go to a foreign land where he often has no contemporary identification.")

234. See supra Subsection II.C.5.

235. See, e.g., Anwar v. INS, 116 F.3d 140. 144 (Sth Cir 1997) (holding that the AEDPA did not eliminate the court's jurisdiction to review the BlA's denal of an alien's molion to reopen his clams for asylum and withholding of deportation); Kolster v. INS. 101 F3d 785 (Ist Cir. 1996) (dismıssing for lack of jurisdiction a petition for review claiming that the BIA erred in interpreting section 212 (c)'s requirement of seven years of "lawful unrelinquished domicile" to mean seven years of "lawful permanent residence").

236. See, e.g., Mojica v. Reno, 970 F. Supp. 130, 137 (E.D.N.Y. 1997). For a discussion of the favorable elements previously considered in an application for section 212(c) relief, see supro note 10

237. See Mojica, 970 F. Supp. at 137 (waming that under the Altomey General's interpretation of the AEDPA in In re Soriano, any person convicted of a mınor crime many years ago "could now be picked up off the streets . . . tom from his or her family, job or busıness, and deported" without the nght to seek a section 212(c) waiver); see also id. at 178 ("[T] he right to spply for the [section 212(c)] watver has been a statutory right which has played a central role in decisions made by crimınally accused lawful permanent residents and other actors in the criminal justice system for decades.").

238. Cf. Colin S. Diver, Statutory Interpretation in the Admimstrative State, 133 U PA. L. REV S49. 579-80 (1985) (suggesting as the strongest rationale for judıcial review that "judges are less likely than agencies to allow personal bias or self-interest to distor thesr reading of the enactor's inteni")

239. See, e.g., Goncalves v. Reno, 1998 WL 236799, at • 17 (Ist Cir. Mas 15. 1998) (rejecting the Attomey General's conclusion that the AEDPA's elimination of section 212 (c) relief applics retroactively to pending applications); Mojtca, 970 F. Supp. at 182 (holding that retroaclive climination of section 212(c) waivers "constitute[s] an arbitrary abuse of power by the Altomes (seneral"). Other distnet courts have 
Suspension Clause itself requires that an alien facing deportation have the opportunity to challenge the executive branch's construction of an immigration statute before a federal court. ${ }^{240}$

Discretionary decisions play an important role in immigration law, and numerous commentators have stressed the need for greater judicial review of such determinations. ${ }^{241}$ This is not simply a matter of public policy, however. Fidelity to the common law writ of habeas corpus requires that the exercise of discretion by an immigration judge be reviewable to ensure that this great power over individual liberty is not exercised arbitrarily. Thus, a criminal alien faced with deportation under the AEDPA and the IIRIRA must have the opportunity for review of his claim of statutory eligibility for section 212(c) relief as well as the chance to challenge a denial of a waiver on the merits. Similarly, the IIRIRA cannot be construed as eliminating judicial review over all discretionary decisions, except asylum, ${ }^{242}$ without running afoul of the Suspension Clause. ${ }^{243}$

In addition, the Suspension Clause requires at least some review of factual findings in deportation proceedings. While questions of fact have not arisen in legal challenges to the jurisdictional provisions of the 1996 acts affecting the deportation of criminal aliens, ${ }^{244}$ factual determinations have traditionally

stated that AEDPA section 440(d)'s elimination of section 212(c) waivers applies retroactively, but nonetheless have held that it violates the Equal Protection Clause to apply section 440 (d) to deportable, but not excludable, legal permanent residents. See Jurado-Gutierrez v. Greene, 977 F. Supp. 1089, 1093 (D. Colo. 1997); Vargas v. Reno, 966 F. Supp. 1537, 1544-47 (S.D. Cal. 1997).

240. Thus, were the Attorney General to apply the expedited removal provisions of IIRIRA to aliens allegedly in the United States for two years or less, see infra text accompanying notes $247-248$, federal courts must still exercise habeas jurisdiction over an alien's claim of statutory construction, such as the criteria necessary to meet the test of two years' continuous residence. See Gail Pendleton, New Removal Proceedings, ImMigR. NEwSL. (National Immigration Project of the Nat'l Lawyers Guild, Inc., Boston), Apr. 1997, at I, 10 (discussing the ambiguity of the regulations). See generally Lucas Guttentag, The 1996 Immigration Act: Federal Court Jurisdiction-Statutory Restrictions and Constitutional Rights, INTERPRETER RELEASES (Federal Publications, Wash., D.C.), Feb. 10, 1997, at 245.

241. See, e.g., Michael G. Heyman, Judicial Review of Discretionary Immigration Decisionmaking, 31 SAN DiEgo L. REv. 861, 865 (1994) (arguing that the "retreat from meaningful judicial review ... represent[s] an unacceptable insensitivity to the human dimension of [immigration] cases"); Danicl Kanstroom, Surrounding the Hole in the Doughnut: Discretion and Deference in US. Immigration Law, 71 TUL. L. REV. 703 (1997); cf. LOUIS L. JAFFE, JUDICIAL CONTROL OF ADMINISTRATIVE ACTION 375 (1965) (" $[T]$ here are very few discretions, however broad, substantially affecting the person or property of an individual which cannot at some point come under judicial surveillance." (emphasis omitted)).

242. See 8 U.S.C.A. $§ 1252(a)(2)(B)$ (West Supp. 1997) (eliminating jurisdiction to review "(i) any judgment regarding the granting of relief" under INA sections 212 (h) (enumerated criminal); 212 (i) (fraud and misrepresentation); $240 \mathrm{~A}$ (cancellation of removal); $240 \mathrm{~B}$ (voluntary departure); 245 (adjustment of status); and "(ii) any other decision . . . which is . . . in the discretion of the Attorney General" except asylum under section 208(a)); see also Pendleton, supra note 240, at 14 (discussing the IIRIRA's elimination of federal judicial review over all discretionary determinations except asylum).

243. Cf. Tefel v. Reno, 972 F. Supp. 608,614 (S.D. Fla. 1997) (stating that the elimination of judicial review over the discretionary decision to stay deportation would "raise serious constitutional issues").

244. Criminal aliens facing deportation under the AEDPA and the IIRIRA have not challenged the underlying criminal convictions for which they are supposedly deportable, but rather have raised legal challenges to, inter alia: (1) the acts' retroactive application, see, e.g., Mojica, 970 F. Supp. at 157; (2) construction of the acts' jurisdictional bar, see, e.g., Choeum v. INS, 129 F.3d 29, 38-39 (1st Cir. 1997) (rejecting the INS's interpretation of AEDPA section 440(a)'s use of "deportable by reason of" to preclude judicial review where the alien was not in fact found deportable for that reason); (3) the effective date of 
been important in determinations of deportability based on economic criteria $^{245}$ or ideology. ${ }^{246}$ Moreover, the IIRIRA's new "expedited removal" provisions, which now govern the admission of aliens to the United States, could also be applied to aliens who allegedly entered the country illegally in the past and have lived continuously in the United States for two years or less. ${ }^{248}$ The expedited removal provisions preclude virtually all judicial review $^{249}$ and thus could lead to the deportation of aliens based on erroneous factual findings. ${ }^{250}$ Such a result would flout the core purpose of the common law writ of habeas corpus.

\section{The Irrelevance of Traditional Reasons for Narrowing Habeas Review}

Even if maintaining the common law core of habeas corpus were not, as I argued in Part I, constitutionally compelled, the factors underpinning the recent decisions by Congress ${ }^{25 !}$ and the Supreme

various provisions of the acts, see, e.g., id. at 35-37 (holding that the IIRIRA's revised definition of "aggravated felony" did not apply to the petitioner's case): and (4) the interpretalion of a precxisting statutory provision, see, e.g., Kolster v. INS, 101 F.3d 785. 787 (1st Cir. 1996) (challenging the INS's interpretation of the provision of section 212 (c) that requires seven years of "lawful unrelinquished domicile").

245. See, e.g., Lisotta v. United States, 3 F.2d 108. 111 (5th Cir. 1924) (holdıng that there was no evidence that the alien was likely to become a public charge at the (ime of his admission to the country).

246. See, e.g., Vajtauer v. Commissioner of Immigration. 273 U.S. 103. 109 (1927) (holding that the deportation of an alien for advocating opposition to all organized government or the overthrow of the United States government by force and violence was supported by some evidence): Mahler v. Eby, 264 U.S. 32, 43 (1924) (holding that the deportation order contained no evidence of a finding that the alien was an "undesirable resident" of the United States).

247. 8 U.S.C.A. § 1225 (West Supp. 1997).

248. Although the Attomey General has yet to apply the expedited removal provisions to nonesuzens residing in the United States, it is within her discretion to do so at anytime. See id. $\$ 1225(\mathrm{~b})(1)(\mathrm{A})(\mathrm{ii})(\mathrm{I})$.

249. See id. $\$ 1225(\mathrm{~b})(1)(\mathrm{A})(\mathrm{i})$ (ordering the removal of suspected illegal aliens seekung to enter the country "without further hearing or review" unless the individual demonstrates to the immigration officer "an intention to apply for asylum ... or a fear of persecution"). The IIRIRA creates a namow exception for review in habeas corpus proceedings. Such review is limited to determining whether the petutioner is an alien, was ordered removed under the expedited removal provisions, and can prove by a preponderance of the evidence that he is a legal permanent resident, has been admitted as a refugee. or has been granted asylum. See id. § 1252(e)(2)(A)-(C).

250. Cf. Inspection \& Expedited Removal of Aliens, 62 Fod. Reg. 10.312, 10,313-14 (1997) (explaining that the application of the expedited removal provisions to those aliens already in the United States would "involve more complex determinations of fact and will be more difficult to manage" than applying them to those seeking admission at the border); see also Pendleton, supra note 240, at 10 (arguing that the regulations provide no guidance on how noncitizens may show two years of continuous physical presence).

251. The AEDPA amends federal habeas corpus in significant ways. Sec. e.g.. AEDPA. Pub. L. No. 104-132, § 101, 110 Stat. 1214, 1217 (1996) (codified at 28 U.S.C.A. $\$ 2244$ (d)(1)-(2) (West Supp. 1997)) (establishing-for the first time ever-a one-year time limitation for filing federal habeas pettions that begins to run, with limited exceptions, after the state cour judgment bocomes final): $t d . \$ 104$. 110 Stat. at 1219 (codified at 28 U.S.C.A. $\$ 2254$ (d)) (requiring increased deference to state court judgments on federal habeas with respect to pure questions of federal law and mixed questions of law and fact); $t d ., 110$ Stat. at 1219 (codified at 28 U.S.C.A. $\$ 2254($ c)) (eliminating exceptions to the presumptuon of correctness of factual findings by state courts and narrowing the circumstances in which an evidentuary heanng may be conducted); id., $\S 106,110$ Stat. at 1220-21 (codified at 28 U.S.C.A. $\$ 2244(b)$ ) (adding restnctions on successive habeas petitions); id., $\S 107,110$ Stat. $1221-26$ (codified al 28 U.S.C.A. $\$ \S 2261-2266$ ) 
Court ${ }^{252}$ to narrow the scope and availability of federal habeas in collateral attacks on criminal convictions do not support restricting review in deportation cases. Several, often overlapping reasons are given for narrowing the scope and availability of federal habeas review, including finality, ${ }^{253}$ comity (or federalism), ${ }^{254}$ and the process-oriented view of legality as fair institutional process rather than substantively correct outcomes. ${ }^{255}$

Regardless of their relative merit for limiting collateral review of criminal convictions, ${ }^{256}$ these concerns underscore precisely why deportation implicates the core purpose of the common law writ and requires a broad scope of review under the Suspension Clause. Unlike the defendant seeking habeas review of a criminal conviction, whose conviction has already received several levels of judicial scrutiny, ${ }^{257}$ an alien facing deportation has received no judicial process at all. ${ }^{258}$ Providing some judicial review of the executive

(establishing special provisions in capital cases to which individual states may "opt-in"). See generally Marshall J. Hartman \& Jeanette Nyden, Habeas Corpus and the New Federalism After the Anti-Terrorism and Effective Death Penalty Act of 1996, 30 J. MARSHALL L. REv. 337, 352-86 (1997) (discussing how the AEDPA amends federal habeas corpus).

252. See, e.g., Felker v. Turpin, 116 S. Ct. 2333 (1996) (upholding the added restrictions on second or successive habeas petitions imposed by the AEDPA); Brecht v. Abrahamson, 507 U.S. 619 (1993) (adopting a less onerous harmless error standard on habeas review); Keeney v. Tamayo-Reyes, 504 U.S. 1 (1992) (adopting a "cause and prejudice" standard for failure to develop facts at trial); Coleman v. Thompson, 501 U.S. 722 (1991) (barring the petitioner from raising an ineffective-assistancc-of-counsel claim on habeas on the ground that there is no constitutional right to counsel in state post-conviction proceedings); McCleskey v. Zant, 499 U.S. 467 (1991) (applying the abuse-of-the-writ doctrine to successive habeas petitions absent a showing of "cause and prejudice"); Teague v. Lane, 489 U.S. 288 (1989) (holding that, with two narrow exceptions, new constitutional rules of criminal procedure will not be applied retroactively on habeas to cases that became final before the new rule was announced); Stono v. Powell, 428 U.S. 465 (1976) (barring federal relitigation of a search-and-seizure claim if the defendant was given a "full and fair" opportunity to litigate the claim in a state proceeding).

For most purposes, these precedents apply equally to state and federal prisoners secking habeas review. See LOW \& JEFFRIES, supra note 83, at 69. Federal review of state convictions may be obtained through 28 U.S.C. $\$ 2254$ (1994); review of federal convictions proceeds under 28 U.S.C. $\$ 2255$, which was enacted in 1948 as an alternative to habeas corpus for federal prisoners and which affords the same relief. See Low \& JEFFRES, supra note 83, at 69.

253. See, e.g., Coleman v. Thompson, 501 U.S. 722, 747 (1991) (stating that "the cost to finality in criminal litigation" is the most significant cost of federal habeas corpus).

254. See Stone, 428 U.S. at 478 n.11 (citing Fay v. Noia, 372 U.S. 391, $425-26$ (1963)); see also Younger v. Harris, 401 U.S. 37, 44 (1971) (stressing that the concept of federalism requires "sensitivity to the legitimate interests of both State and National Governments").

255. The most oft-cited argument on this score is that of Professor Paul M. Bator. See Bator, supra note 50; see also Gary Peller, In Defense of Federal Habeas Corpus Relitigation, 16 HARV. C.R.-C.L. L. REV. 579, 586-90 (1982) (summarizing Professor Bator's view).

256. Compare Bator, supra note 50, at 462 (arguing for restrictive federal habeas review where the defendant has had a "full and fair" hearing in a state court), with Peller, supra note 255, at 582 (claiming that "federal habeas review is justified not by an ideal model of federal and state relations, but by the actual refusal of state courts to vindicate federal rights during various periods of American history").

257. The principle that defendants must first exhaust all remedies provided by the appellato process before gaining post-conviction habeas review was established in Ex parte Royall, 117 U.S. 241 (1886), and is now codified in federal habeas statutes, see, e.g., 28 U.S.C. $\$ 2254(\mathrm{~b})(1)(\mathrm{A})$-(B) (1994) (barring habeas relief to those in custody pursuant to a state court judgment absent exhaustion of state court remedies, or absent available or effective "[s]tate corrective process").

258. Cf. Lonchar v. Thomas, 116 S. Ct. 1293, 1299 (1996) ("Dismissal of a first federal habeas petition is a particularly serious matter, for that dismissal denies the petitioner the protections of the Great Writ entirely, risking injury to an important interest in human liberty."). 
branch's interpretation of statutes governing deportation is quite distinct from the "endless repetition of inquiry into facts and law in a vain search for ultimate certitude" that is often associated with collateral review of criminal convictions, particularly death penalty cases. ${ }^{259}$ In a fundamental sense, federal habeas review of an administrative deportation order is not collateral at all.

Federalism-based concerns about habeas are likewise irrelevant because deportation in no way implicates the integrity of procedures "employed by a coordinate jurisdiction within the federal system." ${ }^{\text {260 }}$ Instead, deportation involves the review of actions of another branch of the federal government, a principle well established since Marbury' v. Madison. ${ }^{261}$

Finally, the process-oriented argument in favor of a narrow understanding of habeas corpus is also inapplicable in the deportation context. That argument is premised on the assumption, itself rooted in the context of collateral review of state convictions, that most petitioners have already received "full and fair" hearings. ${ }^{262}$ The argument quickly falls apart when applied to quasi-judicial proceedings held under the authority of the executive branch. ${ }^{263}$ Like review of state convictions, such proceedings implicate the special prominence of federal courts in protecting federal rights. ${ }^{264}$ In addition, however, they involve the even more basic right to adjudication by a neutral institution. It is one thing to restrict habeas corpus when the individual has the right to direct

259. Bator, supra note 50, at 452 . The Supreme Cour has created a narrow exception to the principle that successive claims will not be reviewed on habeas absent a showing of cause and prejudice, otherwise known as the "actual innocence" or "fundamental miscarriage of justice" exception. Sec. e.g. Schlup v. Delo, 513 U.S. 298, 318-23 (1995) (discussing the development and purpose of the exceptron); see also Sawyer v. Whitley, 505 U.S. 333, 345 (1992) (describing the "actual innocence" standard for successive habeas petitions as a "narrow" exception to the principle of finality). See generally Finendly, supra note 56. at 160 (proposing an exception to the concept of finality where the petitioner has made a "colorable showing of innocence"). This narrow exception, created in the context of reviewing successive petitions challenging death sentences, is inapplicable to the deportation context where the petitioner has had no prior judicial review whatsoever.

260. Wainwright v. Sykes, 433 U.S. 72, 88 (1977); cf. LaDuke v. Nelson, 762 F.2d 1318, 1324.25 (9th Cir. 1985) (arguing that the prudential limitations on federal injunctive relief interfering with state law enforcement and criminal justice institutions do not apply to federal injunctive relief aganst federal immigration officials). Similarly, the Court's refusal to review child custody determinations on federal habeas—notwithstanding evidence that such determinations were reviewable at common law-was based on concerns about federalism that are wholly inapplicable to the immigration context. See Lehman v. Lycoming County Children's Serv. Agency, 458 U.S. 502. 514 (1982) (“'R]eliance on what may be appropriate within the federal system or within a state system is of little force where-as in this case-a state judgment is attacked collaterally in a federal coun."). Review of deportation does not involve the "relitigation of a final state-court judgment," id. at 512, but rather review of a nonjudicial determination by a coordinate federal branch.

261. 5 U.S. (1 Cranch) 137,177 (1803) ("It is emphatically the province and duty of the judictal department to say what the law is.").

262. Bator, supra note 50 , at 462 .

263. Notably, Professor Bator himself has argued that an Aricle III court should have ultimate power to control the legality and constitutionality of agency adjudication. See Paul M. Bator. The Constiturton as Architecture: Legislative and Administrative Courts Under Article III. 65 IND. LJ. 233, 267-68 (1990).

264. See Yackle, supra note 223, at 1019 (arguing that habeas ought to guaraniee a federal forum to those claiming federal rights). 
appeal before a judicial organ; it is another thing altogether when one may appeal only to an administrative body, such as the BIA, which the Attorney General may overrule. ${ }^{265}$ In short, reviewability of deportation orders before an Article III court implicates the "institutional" and "functional" role of habeas ${ }^{266}$ - to ensure the separation of powers and to protect against arbitrary enforcement of the law by the executive.

\section{CONCLUSION}

This Note has challenged long-established assumptions about the writ of habeas corpus. It demonstrates that the common law writ of habeas corpus, which the Supreme Court has consistently described as an authoritative guide to interpreting the Suspension Clause, not only applies to aliens facing deportation, but also supports a broad scope of review. At a time when immigrants in the United States face an angry backlash intent on reducing their access to the federal courts, they may turn to one of the oldest and most exalted forms of action in the common law tradition. While the Court has always paid homage to the Great Writ, it can now fully recognize the common law writ's core value and purpose by declaring unconstitutional the judicial review provisions of the 1996 immigration acts, should they be construed to limit review solely to constitutional claims.

265. See supra notes 216-222 and accompanying text (discussing the authority of the Attomey General to overnule the BIA).

266. Bator, supra note 50 , at $448-49$. 